\title{
Seasonal and inter-annual community structure characteristics of zooplankton driven by water environment factors in a sub-lake of Lake Poyang, China
}

\author{
Beijuan Hu ${ }^{1}$, Xuren Hu ${ }^{1}$, Xue Nie ${ }^{1}$, Xiaoke Zhang ${ }^{2}$, Naicheng Wu ${ }^{3}$, Yijiang Hong ${ }^{\text {Corresp., } 1}$, Hai Ming Qin ${ }^{\text {Corresp. } 4}$ \\ ${ }^{1}$ School of Life Science and Center for Watershed Ecology of Institute of Life Science, Nanchang University, Nanchang, China \\ 2 Research Center of Aquatic Organism Conservation and Water Ecosystem Restoration in University of Anhui Province, Anqing Normal University, Anqing, \\ China \\ 3 Aarhus Institute of Advanced Studies, Aarhus University, Aarhus, Denmark \\ ${ }^{4}$ School of Life Science and Center for Watershed Ecology of Institute of Life Science; School of Life Sciences;jiangxi Province Key Laboratory of \\ Watershed Ecosystem Change and Biodiversity, Nanchang University; Qufu Normal University, Qufu, China \\ Corresponding Authors: Yijiang Hong, Hai Ming Qin \\ Email address: yjhong2008@163.com, qinhaiming-haha@163.com
}

Background. Sub-lakes are important for the maintenance of the ecosystem integrity of Lake Poyang, and zooplankton play an important role in its substance and energy flow.

Methods. A seasonal investigation of zooplankton was conducted in spring (April), summer (July), autumn (October) and winter (January of the following year) from 2012 to 2016in a sub-lake of Lake Poyang. The aim of the present study was to understand the seasonal dynamics and interannual variation of zooplankton communities and their relationship to environmental factors.

Results. A total of 115 species were identified in all samples in the four years, which comprised of 87 Rotifera, 13 Cladocera and 15 Copepoda. Rotifera was the dominant group in terms of quantity, and its species richness and abundance were significantly higher when compared to Cladocera and Copepoda $(P<0.05)$, while Cladocera dominated in terms of biomass. The species richness of Rotifera exhibited a significant seasonal difference $(P<0.05)$. Both the density and biomass of zooplankton revealed significant seasonal differences $(P<0.05)$. In general, the density and biomass of zooplankton were higher in summer and autumn, when compared to winter and spring. Biodiversity indices were dramatically lower in spring than in the other seasons. The non-metric multidimensional scaling (NMDS) analysis suggested that these zooplankton communities can be divided into three groups: spring community, summer-autumn community, and winter community. The seasonal succession of zooplankton communities did not have interannual reproducibility. In high water level years, the dominant species of zooplankton (Cladocerans and Copepods) in the wet season had a lower density, and the result in low water level years was exactly the opposite. The redundancy analysis revealed that water temperature (WT), conductivity, $\mathrm{pH}$ and dissolved oxygen (DO) had significant effects on the zooplankton community.

Conclusions. The community structure of zooplankton has a significant seasonal pattern, but has no interannual repeatability. In high water level years, the dominant species of zooplankton (Cladocerans and Copepods) in the wet season had a lower density, and the result in low water level years was exactly the opposite. The density, biomass and diversity indices of zooplankton were significantly different in different seasons. The present study was helpful in the further understanding of the ecosystem stability of lakes connected with rivers, providing scientific guidance for the protection of lake wetlands.

Peer] reviewing PDF | (2019:01:34721:2:0:NEW 28 Jul 2019) 
1 Seasonal and interannual community structure characteristics of zooplankton driven by

2 water environment factors in a sub-lake of Lake Poyang, China

4 Beijuan $\mathrm{Hu}^{1}$, Xuren $\mathrm{Hu}^{1}$, Xue $\mathrm{Nie}^{1}$, Xiaoke Zhang ${ }^{4}$, Naicheng Wu${ }^{1,5}$, Yijiang Hong ${ }^{1}$, Haiming 5 Qin $1,2,3$

$6{ }^{1}$ School of Life Science and Center for Watershed Ecology of Institute of Life Science,

7 Nanchang University, Nanchang, Jiangxi Province, China

$8{ }^{2}$ School of Life Sciences, Qufu Normal University, Qufu, Shandong Province, China

$9{ }^{3}$ Jiangxi Province Key Laboratory of Watershed Ecosystem Change and Biodiversity, Nanchang

10 University, Nanchang, Jiangxi Province, China

$11{ }^{4}$ Research Center of Aquatic Organism Conservation and Water Ecosystem Restoration in

12 University of Anhui Province, Anqing Normal University, Anqing, Anhui Province, China

$13{ }^{5}$ Aarhus Institute of Advanced Studies, Aarhus University, Høegh-Guldbergs Gade 6B, Aarhus

14 C, Denmark

Corresponding Author:

Yijiang Hong1, HaimingQin¹, 2,3

Nanchang City, Jiangxi Province, China

Email address: yjhong2008@163.com, qinhaiming-haha@163.com

Abstract

Background. Sub-lakes are important for the maintenance of the ecosystem integrity of Lake Poyang, and zooplankton play an important role in substance and energy flow.

Methods. A seasonal investigation of zooplankton was conducted in spring (April), summer (July), autumn (October) and winter (January of the following year) from 2012 to 2016 in a sub- 
27 lake of Lake Poyang. The aim of the present study was to understand the seasonal dynamics and 28 interannual variation of zooplankton communities and their relationship with the environment.

29 Results. A total of 115 species were identified in all samples over four years, comprising of 87 30 Rotifera, 13 Cladocera and 15 Copepoda. Rotifera was the dominant group in terms of quantity, 31 and its species richness and abundance were significantly higher when compared to Cladocera 32 and Copepoda $(P<0.05)$. Cladocera dominated in terms of biomass. The species richness of 33 Rotifera exhibited a significant seasonal difference $(P<0.05)$. Both the density and biomass of 34 zooplankton revealed significant seasonal differences $(P<0.05)$. In general, the density and 35 biomass of zooplankton were higher in summer and autumn than in winter and spring. 36 Biodiversity indices were dramatically lower in spring than in the other seasons. Non-metric 37 multidimensional scaling (NMDS) analysis suggested that these zooplankton communities can 38 be divided into three groups: spring community, summer-autumn community, and winter 39 community. The seasonal succession of zooplankton communities did not have interannual reproducibility. In high water level years, the dominant species of zooplankton (Cladocerans and Copepods) in the wet season had a lower density. The result in low water level years showed exactly the opposite. The redundancy analysis revealed that water temperature (WT), conductivity, $\mathrm{pH}$ and dissolved oxygen (DO) had significant effects on the zooplankton 44 community.

Conclusions. The community structure of zooplankton has a significant seasonal pattern, but no interannual repeatability. In high water level years, the dominant species of zooplankton (Cladocerans and Copepods) in the wet season had a lower density, and the result in low water level years was exactly the opposite. The density, biomass and diversity indices of zooplankton were significantly different during the changing seasons. The present study will be helpful in further understanding the ecosystem stability of lakes connected to rivers, providing scientific guidance for the protection of lake wetlands.

\section{Introduction}

Lake Poyang is the largest freshwater lake in China. It is a connected lake, in which water levels fluctuate widely during different seasons (Wu, 1994). In Lake Poyang's low water period, 
56 more than 100 separated sub-lakes appear (Hu et al., 2015). When these sub-lakes connect with 57 the main lake in the high water period, a close exchange of material, energy and biology occur 58 among these water bodies. Sub-lakes are of significant ecological value due to their huge vegetation biomass (Huang \& Guo, 2007; Li \& Liu, 2001), high biodiversity (Wu, 1994; Ge et al., 2010), fish nurseries and reproduction sites in the high water period (Zhang \& Wang, 1982), and ideal habitats provided for wintering birds (Qi et al., 2011; Hu and Ge et al., 2014). All these characteristics play important and unique roles in maintaining the biological integrity and species diversity of the Lake Poyang wetland ecosystem.

Zooplanktons are essential for maintaining the health and stability of aquatic ecosystems, acting as a link between the primary producer and higher consumers. The trophic state of lakes can also be accurately reflected by the spontaneous variation in zooplankton (Pereira et al., 2002; Krylov, 2015). Zooplankton communities have significant seasonal fluctuations under the influence of biotic and abiotic factors. Environmental factors such as total nitrogen (TN), total phosphorus (TP), water temperature (WT), water clarity and the biomass of microalgae all play important roles in the succession of zooplankton communities (Yang et al., 2014; Hu and Yang et al., 2014). The periodical connection between lakes and rivers also affects the ecological structure and function of zooplankton communities. Different water levels have different degrees of effect on zooplankton (Goździejewska et al., 2016). Planktivorous fish exert high top-down control on zooplankton, especially on macro-zooplankton, which may lead to a decrease in the number of Daphnia (Scheffer et al., 1997) and the miniaturization of the zooplankton community.

The increase of $\mathrm{N}$ and P levels in recent decades (Lv, 1996; Wang et al., 2008) has led to the eutrophication of Lake Poyang. In 2011, the Jiangxi Water Resources Bulletin (2012-2015) indicated that the water of Lake Poyang exhibited moderate eutrophication (http://www.jxsl.gov.cn/) when the average TN was $1.389 \mathrm{mg} / \mathrm{L}$ and TP was $0.067 \mathrm{mg} / \mathrm{L}$ (Chen et al, 2013). Although Lake Poyang has reached the level of eutrophication, there was fortunately no outbreak of cyanobacteria bloom due to both the connection of the lake with the Yangtze River and seasonal fluctuations in water level (Hu \& Zhu, 2014). However, cyanobacterial blooms have already taken place in Lake Poyang's sub-lakes due to unmanaged development and resource utilization (Dai et al., 2015). The state of the sub-lakes reflect the environmental 
86

87

88

89

90

91

92

93

94

95

96

97

98

deterioration of Lake Poyang, and their ecological decline may eventually seriously affect the lake's wetland ecosystem and function.

The first study of zooplankton in Lake Poyang focused on the species in the 1960s (Deng et al., 1963). Subsequently, other discontinuous research on zooplankton have been conducted, but these studies were relatively limited. For example, Xie et al. (1997, 1998 and 2000) carried out an annual dynamic research on zooplankton in Lake Poyang; Wang et al. (2003) catalogued 150 zooplankton species in the spring and winter; and Liu et al. (2016) characterized the features of all crustaceans. According to records (Huang \& Guo, 2007), there is a total of 207 zooplankton species in China but reports on zooplankton in the sub-lakes of Lake Poyang have remained very limited in the past decades. Zooplankton in sub-lakes were reported only in recent years (Zhang et al., 2014). Furthermore, there are very few reports on seasonal and annual variations in zooplankton communities in sub-lakes. Zooplankton are the main feeding target of many fishes, and their distribution and variation can be used as a scientific basis for exploring fish stocks and finding fishing grounds (Huang et al., 2010). At the same time, zooplankton are also important indicators of aquatic environmental change (Peter et al., 2010). Their population structure, quantity, and dominant species can be important indicators for monitoring water quality (Wang, et al., 2012). Therefore, studying the spatial and temporal distribution pattern of zooplankton can provide a vital scientific basis for the protection and sustainable utilization of lake resources.

The present study carried out a preliminary research of the seasonal variations of zooplankton communities in Shahu Lake, a sub-lake of Lake Poyang. The samples were collected seasonally from April 2012 to January 2016. The specific aims were as follows: (1) to investigate the seasonal and interannual variations of zooplankton communities in a sub-lake, and (2) to identify the dominant physicochemical factors that affect the variation in zooplankton community structures.

\section{Materials \& Methods}

\section{Sampling site}

Lake Poyang $\left(28^{\circ} 24^{\prime}-29^{\circ} 46^{\prime} \mathrm{N}, 115^{\circ} 49^{\prime}-116^{\circ} 46^{\prime}\right)$ is located downstream of the Yangtze River (Fig. 1-A). It has an area of $3,210 \mathrm{~km}^{2}$ in the highest water level period and $146 \mathrm{~km}^{2}$ in the lowest water level period (Zhang, 1988). Its catchment has a subtropical monsoon climate with 
116 an average annual rainfall of $1,400-1,900 \mathrm{~mm}$, and an average annual temperature of 16.7-17.7 $117{ }^{\circ} \mathrm{C}(\mathrm{Wu}, 1994)$. Jiangxi Poyang Lake National Nature Reserve lies to the northwest of Lake 118 Poyang (Fig. 1-B), and there are nine sub-lakes in the reserve. One of these is Shahu Lake, which 119 has a surface area of $1.4 \mathrm{~km}^{2}$, a flat bottom, and few submerged plants (Fig. 1-C). There is 120 significant seasonal water level fluctuation in Shahu Lake. The maximum water fluctuation 121 amplitude is approximately $6 \mathrm{~m}$ between flood and dry seasons. During the dry season, local 122 fishermen fish in the lake using a method known as "lake enclosed in autumn". This involves the 123 fishermen discharging water through a water-gate, and fishing with a long mesh bag fixed at its 124 gate from October to January of the next year. Using this process, the water level gradually 125 decreases to $0.2-0.3 \mathrm{~m}$.

\section{Sampling design}

Zooplankton were seasonally sampled (spring $=$ April, summer $=$ July, autumn $=$ October and

128

129

130

131

132

133

134

135

136

137

138

139

140

141

142

143

144

145

146 winter $=$ January) at three points in Shahu Lake from April 2012 to January 2016. With the water level declining, the water only remained in the deepest area, and the water depth was approximately only $0.2-0.3 \mathrm{~m}$. Therefore, these three sampling points in winter were set in areas of the lake where the water depth was more than $1.4 \mathrm{~m}$ in autumn 2012 (Fig. 1-D). Zooplankton were sampled three times at each point, and nine samples were collected in each season, resulting in a total of 144 samples over four years. A 5-L modified Schindler-Patalas sampler was used to collect $10 \mathrm{~L}$ of mixed water at approximately $50 \mathrm{~cm}$ below the water surface for each sample. A plankton net (mesh size, $64 \mu \mathrm{m}$ ) was used to filter the water and collect the zooplankton, which gathered at the end of the net, and these were immediately preserved in 50 $\mathrm{mL}$ plastic bottles with $4 \%$ formalin. In the laboratory, the zooplankton were counted and identified under a microscope (Olympus SZ61, Japan and Olympus CX23, Korea). When there were excessive individuals in one sample, a sub-sample method was used to estimate the actual quantity. In the present study, copepod nauplii were considered as one taxon. Four bibliographies, including three faunas, were used for zooplankton identification (Wang, 1961; Crustacean Research Group, 1979; Jiang \& Du, 1979; Han \& Shu, 1995).

At the time of collection, the physicochemical parameters of $\mathrm{WT}, \mathrm{pH}$, conductivity (Cond), dissolved oxygen (DO) and turbidity (Turb) were simultaneously measured using a multifunction water quality monitor (YSI6600V2, USA).

\section{Data analysis}


147 In the present study, zooplankton community characteristics mainly include the dominant 148 species, diversity index, density, biomass and community clustering map.

149 The dominance index was calculated as follows:

150

151

152

153

154

155

156

157

158

159

160

161

162

163

164

165

166

167

168

169

170

171

172

173

174

175

176

177

$$
Y=\mathrm{n}_{i} \times \mathrm{f}_{i} / N \text { (Eqn. 1) }
$$

In which $Y$ represented the dominance index, $\mathrm{n}_{i}$ represented the individual number of $i$ species, $\mathrm{f}_{i}$ represented the occurrence frequency of $i$ species, and $N$ represented the total number of individuals. When $Y$ was greater than or equal to 0.02 , this species was defined as dominant species. In the present study, $N$ referred to the total density of zooplankton in each season (Wen et al., 2015).

The Shannon-Weiner diversity index $\left(H^{\prime}\right)$, Margalef richness index $(D)$ and Pielou evenness index $\left(J^{\prime}\right)$ calculation formulae were as follows:

$$
\begin{gathered}
H^{\prime}=-\sum P_{i} \ln \left(P_{i}\right) \\
D=(S-1) / \ln N \\
J^{\prime}=H^{\prime} / \ln S \quad \text { (Eqn. 2) }
\end{gathered}
$$

Where $S$ represented the species number and $P_{i}$ represented the proportion of $i$ species densities in the total zooplankton density in the sample (Wen et al., 2015).

The densities of zooplankton were calculated by dividing the individual numbers of zooplankton that gathered in each collection by the sample volume, and this was expressed in ind./L. The biomass of zooplankton (wet weight) was evaluated according to the method reported by Zhang and Huang (1991). The weight of each nauplii was estimated to be approximately $0.003 \mathrm{mg}$ (Xie \& Li, 1998).

The seasonal variance of water physicochemical factors, zooplankton density and biomass were analysed by one-way ANOVA, using STATISTICA 7.0 (StatSoft Inc., Tulsa OK, USA). The seasonal variation in zooplankton communities was tested by non-metric multidimensional scaling analysis (NMDS) and analysis of similarities (ANOSIM). Zooplankton individual number data were analysed using a ranked similarity matrix based on Bray-Curtis similarity measures. Rare species, which had an average density of less than 1.0 ind./L, were excluded during NMDS and ANOSIM analyses. NMDS ordination and ANOSIM analyses were performed with the PRIMER 5 computer package (Clarke \& Warwick, 1994). The indicator value method (IndVal) was used to detect how strongly each species discriminated among the NMDS groups. The indicator value of a taxon varied from 0 to 100 , and the indicator value 
178 attained its maximum value when all individuals of a taxon occurred at all sites within a single 179 group (Szulc et al., 2010). The significance of the indicator value for each species was tested 180 with a Monte Carlo randomization procedure with 1,000 permutations. IndVal was performed 181 using the indval function in $\mathrm{R}$ package labdsv ( $\mathrm{R}$ version 3.4.1, $\mathrm{R}$ Development Core 182 Team2017).

183 The correlation between water physicochemical factors and zooplankton dominant species was 184 analysed using redundancy analysis (RDA), and the significance was determined using the 185 Monte Carlo test. The RDA and Monte Carlo tests were performed using Canoco for Windows 1864.5 software (Ter Braak \& Smilauer 2002). With the exception of the NMDS analysis, all 187 variables were transformed by $\ln (\mathrm{x}+1)$ prior to analysis.

\section{Results}

\section{Physical-chemical variables}

191

The mean seasonal values of physicochemical factors in Shahu Lake from April 2012 to 192 January 2016 are presented in Table 1. The one-way ANOVA revealed that all physicochemical 193 factors had significant seasonal differences $(P<0.05)$. After spring, WT increased, reaching a maximum $\left(\sim 29.4^{\circ} \mathrm{C}\right)$ in summer, fell in autumn and dropped to a minimum $\left(\sim 9.2^{\circ} \mathrm{C}\right)$ in winter. Conductivity had an average range $( \pm \mathrm{SE})$ from $90.2 \pm 15.4$ to $532.6 \pm 446.2 \mu \mathrm{S} / \mathrm{cm}$ with a minimum value of $60.7 \mu \mathrm{S} / \mathrm{cm}$ in April 2013 and a maximum value of $1049 \mu \mathrm{S} / \mathrm{cm}$ in October 2013. DO and water turbidity were highest $(11.0 \pm 1.2 \mathrm{mg} / \mathrm{L}$, and $142.1 \pm 75.2 \mathrm{NTU}$, respectively) in winter and lowest $(5.9 \pm 2.1 \mathrm{mg} / \mathrm{L}$, and $35.1 \pm 27.4 \mathrm{NTU}$, respectively) in summer. In contrast, $\mathrm{pH}$ was lowest $(6.7 \pm 0.6 \mathrm{mg} / \mathrm{L})$ in winter and highest $(7.6 \pm 0.7 \mathrm{mg} / \mathrm{L})$ in summer.

200

201

202 203 204 205

\section{Species composition}

\section{Species richness}

A total of 115 species of zooplankton were found (Appendix Table 1). There were 87 species of Rotifera, 13 species of Cladocera and 15 species of Copepoda. These three main species made up $76.1 \%, 11.1 \%$ and $12.8 \%$ of the total species number, respectively. Zooplankton species richness had no significant interannual variation. There were 56 species captured in 2012, 65 
206 species in 2013, 61 species in 2014 and 72 species in 2015 (Fig. 2). Only 24 species appeared 207 simultaneously over the four years: 18 rotifera species, two cladocera species and four copepoda 208 species. Zooplankton species richness exhibited significant seasonal differences $(P=0.041)$. 209 Rotifers, which made up $36.4-81.3 \%$ of the total species number, were the dominant component 210 in every season. A total of 58 species was found in spring with the minimum (11 species) in 2112014 and the maximum (34 species) in 2015. There were 88 species collected in summer, with 212 the minimum (33 species) in 2014 and the maximum (48 species) in 2013 and 2015. In autumn, 21372 species were captured, and the minimum (23 species) were found in 2012 and the maximum 214 (42 species) were found in 2014. In winter, 65 species were identified, and the minimum (23 215 species) were found in 2012 and the maximum (35 species) were identified in 2015.

\section{Dominant species}

217 There were 13 dominant species, 10 dominant species, 16 dominant species and eight 218 dominant species in each year from 2012 to 2015 (Table 2). Bosmina longirostris, copepod 219 nauplii and Microcyclops varicans dominated over the four years. In spring, Keratella cochlearis 220 and Conochilus unicornis were dominant species. Specifically, spring 2014 saw the outbreak of 221 C. unicornis which led to the highest density (1908.8 ind./L) of rotifers. In summer and autumn, 222 the dominant genera of rotifers were Brachionus, Keratella, Polyarthra, Asplanchna and 223 Trichocerca. In winter, the dominant species were replaced by Polyarthra dolichoptera, 224 Synchaeta oblonga, K. cochlearis, C. unicornis and A. priodonta.

\section{Zooplankton density and biomass}

\section{Seasonal variation}

227

228

229

230

231

232

233

234

Total density of zooplankton showed similar trends with species richness (Fig.3-A). In general, maximum density occurred in summer or autumn and minimum density appeared in spring or winter. Zooplankton density was highest in autumn (140.0 ind./L), followed by summer (83.0 ind./L) and spring (56.9 ind./L). The minimum density was found in winter (1.3 ind./L). Rotifer density showed no significant seasonal difference $(P=0.123)$. However, the densities of cladocerans and copepods in winter were significantly lower when compared to the other seasons $(P<0.001)$. The maximum density of cladocerans was observed in October 2014 (219.2 ind./L), while the maximum density of copepods was observed in July 2014 (137.6 ind./L). 
235

236

237

238

239

240

241

242

243

244

245

246

247

248

249

250

251

252

253

254

255

256

257

258

259

260

261

262

263

The biomass of zooplankton was significantly lower in winter (Fig. 3-B) when compared to the other seasons $(P<0.05)$. The highest biomass of rotifers was in autumn, and the lowest was in winter. The biomass of both cladocerans and copepods was highest in spring and lowest in winter. Although the density of cladocerans was lower than those of rotifers and copepods, they contributed $50 \%$ of the total biomass of zooplankton and were 1.7 times and 1.9 times the biomass of rotifers and copepods.

\section{Interannual variation}

The interannual variation in zooplankton density was significant $(P=0.012)$. The density in 2014 was significantly higher than in the other three years (Fig.4-A). The outbreak of $C$. unicornis in spring 2014 resulted in the highest density of rotifers $(P=0.018)$. The density of cladocera in 2014 was significantly higher than in 2012 and $2015(P=0.039)$. The biomass of zooplankton in 2015 was significantly lower than in the other three years $(P=0.036$, Fig. 4-B). The density and biomass of zooplankton in spring 2015 was very low (18.2 ind./L, $0.16 \mathrm{mg} / \mathrm{L}$, respectively), and the density and biomass of 2015 were lower than in previous years.

\section{Species diversity index}

There was some fluctuation in the zooplankton diversity index over the 16 seasons (Fig. 5). The Shannon-Weiner index (H') was in the range of 0.2-3.1 (Fig. 5-A), with an average of 2.37. The Margalef index (D) was in the range of 1.1-7.6 (Fig.5-B), with an average of 4.2. Pielou's evenness index $\left(\mathrm{J}^{\prime}\right)$ was in the range of 0.09-0.85 (Fig.5-C), with an average of 0.69. The results of the one-way ANOVA revealed that the Shannon-Wiener index and Pielou's index had significant seasonal variation $(P<0.001$, and $P=0.002$, respectively). The seasonal variation in the Margalef index was not significant.

\section{Community structure}

The NMDS results revealed that, apart from July 2012, zooplankton in July and October in all four years were at a high density and had similar dominant species. In addition, these were combined as a summer-autumn community (Fig. 6). Zooplankton in January were categorized as a low-density winter community. The zooplankton community in July 2012 and April in all four years were separated into independent branches because the species composition and density of zooplankton in these seasons were quite different from those in the other seasons. During the 
264 month, the species composition and diversity of zooplankton were quite different and formed 265 separate communities. However, the inter-annual zooplankton communities could not be 266 distinguished from each other. This result indicated that the seasonal variation of the zooplankton 267 community structure in Shahu Lake was greater than the interannual variety. In order to identify 268 the key indicator species of the three main NMDS groups (i.e., spring, summer-autumn and 269 winter), we used the indicator value method (IndVal), and it was revealed that the three groups 270 were characterized by different indicator species (Appendix Table 2).

\section{Redundancy analysis of zooplankton and environmental factors}

272 Before the redundancy analysis (RDA), a preliminary detrended correspondence analysis 273 (DCA) on species-sample data produced the longest gradient length of 3.184, suggesting that 274 both RDA and canonical correspondence analysis (CCA) were appropriate. The RDA was 275 selected to illustrate the relationships between the dominant species of zooplankton and 276 environment factors (Fig.7). The first axis explained the 15.6\% of variance in the species data, 277 and the $50 \%$ of variance in the species-environment relationship (Table 3 ). The second axis 278 explained the $7.4 \%$ of variance in species data, and the $23.7 \%$ of the variance in the species279 environment relationship. The Monte Carlo permutation test revealed that WT $(P=0.002)$, 280 conductivity $(P=0.002), \mathrm{pH}(P=0.018)$ and DO concentrations $(P=0.026)$ had significant effects 281 on zooplankton communities. WT had a higher correlation with Axis $1(\mathrm{R}=0.695)$, and Spearman 282 rank correlation analysis indicated that WT had a significant positive correlation with 283 zooplankton $(\mathrm{R}=0.722, P<0.05)$.

284

285

\section{Discussion}

Temporal pattern of zooplankton communities in the sub-lake

Rotifera are an important component of zooplankton communities in a freshwater lake. Their small size, fast growth rate and parthenogenetic reproduction (Gilbert, 1999; Inaotombi et al., 289 2016) lead to a generally dominant abundance (Romo, 1990). In the present study, rotifers were also the dominant group in Shahu Lake. The quarterly survey from 2012-2015 identified 87 Rotifers, 13 Cladocerans and 15 Copepods, with an average of 63 species each year. However, the species richness was lower when compared with the historical research records of Lake 293 Poyang (Xie et al., 1997, 1998; Wang et al., 2003; Huang \& Guo, 2007). The density of three species (B. longirostris, Copepod nauplii and M. varicans) of zooplankton that were dominant 
295 species in four years were separately analyzed, and it was found that the density changes had 296 similar patterns (Fig. 8). In both the flood season (summer) and retreat period (autumn), the 297 density of these three zooplankton were significantly lower in high water level years than in low 298 water level years. The comparative analysis revealed that these changes were closely correlated 299 to the inter-annual hydrological situation (Gal et al., 2014), and that these might have 300 correlations with the varying number of fishes entering the lake under different water levels. 301 Usually, these three dominant species (all crustaceous zooplankton) are food resources for 302 planktonic feeding fishes (Mamani et al., 2019). Hence, the predation pressures caused by fish 303 might be the direct cause of changes in zooplankton density. The habitat diversity of Lake 304 Poyang is higher than that of Shahu Lake, its sub-lake. Furthermore, the samples in the present 305 study were only taken in the open water area, and the lake has faced intensive human activities, 306 such as beach grazing, fishing, eutrophication caused by pollution, etc. These objective factors 307 may have led to a decrease in species richness. The NMDS analysis suggested that seasonal 308 variation was more significant than interannual in the zooplankton community structure, and that 309 this could be divided into three community groups associated with distinct indicator species (Fig. 310 6, Appendix Table 2). Previous studies of zooplankton in Lake Poyang (Xie et al., 1997, 1998; 311 Liu et al., 2016) have roughly observed the seasonal dynamics of the zooplankton community 312 structure. Rotifers peaked in summer and autumn. Cladocerans and copepods achieved their 313 peaks in spring, summer and autumn. However, all three groups were at minimum levels in 314 winter. The present study also showed the same seasonal dynamic patterns. Though the sub-lake 315 was separated from Lake Poyang in the dry season, the seasonal dynamics of the zooplankton 316 community in Shahu Lake were similar to those of Lake Poyang. Similar patterns of seasonal 317 changes in the zooplankton community have been reported in other lakes (Hu \& Yang, 2014; Lin 318 et al., 2014).

319 The density and biomass of zooplankton exhibited a significant difference among seasons $320(P=0.035, P=0.002)$. Over the four years, rotifers were the main component of zooplankton, 321 representing $72.3 \%$ of the total zooplankton abundance with 6.5 times and 4.4 times the density 322 of cladocerans and copepods, respectively. Zooplankton density was highest in autumn and 323 lowest in winter. With one exception, the maximum density (1971.0 ind./L) occurred in spring 3242014 due to the outbreak of $C$. unicornis. The biomass of zooplankton was significantly lower in 325 winter than in other seasons $(P<0.05)$. The highest biomass of rotifers was in autumn and lowest 
326 in winter. An earlier study reported that cladocerans and copepods are the main component of 327 zooplankton productivity due to their larger body size (Castro \& Gonçalves, 2007). In the present 328 study, we also found that the biomass of both cladocerans and copepods was highest in spring. 329 Although the density of cladocerans was lower than rotifers and copepods, this contributed to $50 \%$ 330 of the total biomass of zooplankton.

331 We found that the seasonal succession characteristics of the zooplankton community in Shahu 332 Lake were consistent with a previously reported model (Sommer, 1986). In winter, the cold 333 temperature and lack of food resulted in a decline in zooplankton reproductive capacity. Thus, a 334 minimum zooplankton density was observed in this period. In spring, the phytoplankton biomass 335 increased with rising temperatures, and they provided a greater food resource to 336 phytoplanktivorous zooplankton (Cladocera and Calanoida). Simultaneously, the hatching of 337 dormant eggs and copepods diapause ontogeny developed into supplementary populations. The result was an increase in zooplankton abundance in spring (Hairston et al., 2000). The numbers of Daphnia gradually decreased after midsummer, and this was replaced by smaller species and copepods (Threlkeld, 1979; Steiner, 2004; Deng et al., 2008). After autumn, with fishing making fish predation less of a threat, the abundance of rotifers rapidly increases, and they become the 342 dominant groups in Shahu Lake.

343 Some studies have found that the spring-summer zooplankton community is not in a complete 344 repetitive succession in small sub-lakes due to the difference in interannual water temperature 345 and rainfall (Rettig et al., 2006). There was a large variation in the spring zooplankton 346 community of the Shahu Lake during the four years, while in the other seasons the community 347 structures tended to be similar. In early spring, Shahu Lake and Lake Poyang were still not 348 connected. Zooplankton communities in Shahu Lake were mainly affected by rainfall, human 349 disturbance and other unspecified factors. Therefore, zooplankton community succession in this 350 period may not have a uniform direction. In summer, however, Shahu Lake was connected with 351 the main lake. The material and biological exchanges between the sub-lake and main lake 352 resulted in a similarity in water environment and biological community structure. Therefore, the 353 zooplankton community succession was back to the early stages (Baranyi et al., 2002).

\section{Effects of environmental factors on the zooplankton community}

355 Water physicochemical factors can affect species composition and the abundance of a 356 zooplankton community. The significant differences in physicochemical factors in different 
357 seasons leads to seasonal zooplankton dynamics (Deyzel 2004). Some studies have pointed out 358 that the seasonal dynamics of zooplankton can be influenced by temperature (Hu et al., 2014; 359 Hussain et al., 2016). Water temperature has an important effect on dormant eggs hatching, 360 growth and the reproduction of zooplankton (Korpelainen, 1986; Hu et al., 2008). For example, 361 the net reproduction rate of Brachionus diversicornis is highest when the temperature is $30{ }^{\circ} \mathrm{C}$ 362 (Ning et al., 2013), which might be the main reason why B. diversicornis is the dominant species 363 in summer in Shahu Lake. Temperature also affects phytoplankton. High temperatures were 364 favourable for the growth of phytoplankton, and the biomass of phytoplankton in Lake Poyang 365 was highest in summer (Wu et al., 2013). Low temperatures limit the predation of zooplankton 366 on phytoplankton (Zheng et al., 2015). Hence, zooplankton in Shahu Lake have a high density in

367 368 369 370 371 372 373 374 375 376 377 378 379 summer and a low density in winter.

Different zooplankton species have different adaptations to temperature (Tao et al., 2008). The number of resting eggs increases in both higher and lower temperatures (Shi \& Shi, 1996). In the present study, it was found that the dominant species in summer were thermophilic species, such as Brachionus spp. and Trichocerca spp., and wide suitable temperature species, such as Keratella spp. The dominant species in winter were those suited for low temperatures, such as Polyarthra dolichoptera, Synchacta spp. and so on. Therefore, the seasonal variation of temperature is one of the reasons for the changing zooplankton dominant species. WT variation was significant in Shahu Lake, and was highest in summer and lowest in winter (Table 1). The RDA suggested that there was a positive correlation between temperature and most of the dominant species. The Spearman rank correlation analysis also revealed that temperature has a positive correlation with species richness $(\mathrm{R}=0.376, P=0.009)$, density $(\mathrm{R}=0.401, P=0.005)$ and biomass $(\mathrm{R}=0.480, P=0.001)$ of zooplankton.

The results of the redundancy analysis revealed that conductivity, $\mathrm{pH}$ and dissolved oxygen also had a significant effect on the seasonal variation of the zooplankton community. Berzins and Pejler (1987) reported that some species of rotifers, which could instruct the water oligotrophic conditions, generally appeared in water at $\mathrm{pH} 7.0$ or slightly lower. Some other species of Rotifera indicated that eutrophic conditions prefer water with a $\mathrm{pH}$ value higher than 7.0. The $\mathrm{pH}$ value of Shahu Lake was higher than 7.0, and its water was at a certain degree of eutrophication. Among its dominant species, such as Brachionus spp., A. brightwelli, S. oblonga, Filinia longiseta, Daphnia pulex, Bosmina longirostris and Bosmina coregoni, most were commonly 
388 found to be indicator species of eutrophication. Phytoplankton blooms can lead to higher water $389 \mathrm{pH}$ values. There is a correlation between phytoplankton and the water $\mathrm{pH}$ value in summer. In 390 the present study, the Spearman rank correlation analysis revealed that significant positive 391 correlations existed between $\mathrm{pH}$, the zooplankton species richness $(\mathrm{R}=0.644, P<0.001)$ and the 392 Shannon-Weiner diversity index $(\mathrm{R}=0.487, P<0.001)$. In the present study, we found that there 393 was a significant positive correlation between conductivity and copepods $(\mathrm{R}=0.463, P<0.001)$, 394 but there was a weakly positive correlation between conductivity and cladocerans $(\mathrm{R}=0.078$, $395 P<=0.597$ ). This was consistent with a previous study (Soto \& Rios, 2006).

396 Water level fluctuation was also one of the important factors that affected the zooplankton 397 community structure. It was found that the density and community structure of zooplankton 398 changed as the water level fluctuated (Goździejewska et al., 2016). As the fluctuation intensified, 399 the former dominant species, Daphnia, was replaced by rotifers (Zhou et al., 2016). The 400 zooplankton composition of Shahu Lake in summer was dominated by small individual rotifers, 401 copepod nauplii and Bosmina longirostris. The main reason for this was that Lake Poyang was in 402 the rising water level period from April to July, and the water level changes resulted in a 403 disturbance to zooplankton. When the water level rose, Shahu Lake was connected with the main 404 lake (Fig 8-C). Consequently, nutrients and other biological communities (such as fishes, Fig 8405 D) poured into the sub-lake along with the flood, and interactions occurred among zooplanktons 406 and other aquatic organisms from rivers. This was probably one of the reasons for the great shifts 407 in the zooplankton community in Shahu Lake from spring to summer. Interval water level 408 differences can also lead to annual zooplankton differences. In the summer of 2012, the water 409 level was significantly higher than in previous years (Fig. 8-C). The continuing high-water level 410 could be the reason why the zooplankton community structure in summer 2012 was significantly 411 different than in other years.

412 Evaporation, seepage flow and the opening of water-gates for fishing from the middle of 413 October resulted in the water level gradually decreasing in Shahu Lake. The water depth was 414 only $20-30 \mathrm{~cm}$ by the end of fishing, exposing most of the lake basin. The lake's bottom sediment 415 and its attachments fully contacted with the atmosphere and the sun. The digestion of organic 416 matter in the sediment was accelerated and the soil structure improved (Hu, 2012). However, the 417 water-gate was not opened during the winter of 2013. Hence, the water depth remained more 418 than one meter during that period (Fig. 8-C). The stability of the water level, coupled with 
419 nutrient enrichment and temperature recovery in spring, maintained a relatively stable 420 environment, leading to the outbreak of the Conochilus unicornis population.

421 Effects of aquatic organisms on the zooplankton community

422 In addition to environmental factors, biological factors are also important in changing 423 zooplankton community seasonal dynamics (Castro \& Gonçalves, 2007). Fish have a choice 424 during predation (Dodson, 1970) and most fish prefer bigger zooplankton (Wang, 2010). Filter425 feeding fishes such as silver carp (Hypophthalmichthys molitrix) and bighead carp (Aristichthys 426 nobilis) have an important place in Shahu Lake (Zeng et al., 2015). After the lake has been 427 enclosed and fished in winter, zooplankton face lower predation pressure from fish at the start of 428 spring. When the water level rises, the floods not only change the zooplankton community 429 structure, but also bring many migrating fishes from the rivers and other lakes. These two factors 430 have led to the miniaturization of zooplankton species. The larger zooplankton, Daphnia hyalina, 431 D. pulex and Sinocalanus dorrii, were dominant in spring. However, the abundance of these 432 species declined sharply in summer, and some species even disappeared from the lake. This 433 suggested a close correlation with fish predation (Scheffer et al., 1997; Steiner, 2004; Deng et al., 2008), and the outbreak of small C. unicornis in spring 2014 may have been related to the absence of Daphnia caused by the end of fishing in winter 2013.

In addition to predation relations between fish and zooplankton, some other aquatic organisms have contributed to zooplankton seasonal dynamics by affecting the water environment. In winter, the grasslands, mudflats and shallow waters provide an excellent habitat for wintering migratory birds, and a large number of migratory birds live in the Lake Poyang. The feces of winter migratory birds lead to an increase of nitrogen and phosphorus concentrations, which increase the eutrophication level of the sub-lakes. The study of the water quality of Shahu 442 through the zooplankton diversity index revealed that spring water quality was worse than that of 443 other seasons (Zhu et al., 2014; Nie et al., 2018). The dynamics of the zooplankton community 444 are ecologically complex, and some factors have not been involved in this experiment. The 445 composition and biomass of phytoplankton, interspecific and intraspecific competition, and nutrient concentration all have an effect on the succession of the zooplankton community.

\section{Conclusion}


449 The community structure of zooplankton has a significant seasonal pattern and no interannual 450 repeatability. The differences in zooplankton density, biomass and diversity indices were 451 significant in different seasons and years. This study will be helpful in the further understanding 452 of the ecosystem stability of lakes connected with rivers, and in providing scientific guidance for 453 the protection of lake wetlands.

454 Overall, ecological civilization construction is very important for the decisions made by the 455 current Chinese government. Promoting green development and strengthening ecological system 456 protections are imperative. As the largest lake in China, Lake Poyang's ecological states are of 457 great importance for the whole Yangtze catchment, and it is a vital part of China's ecological 458 civilization construction, including biodiversity conservation, and water resource planning and 459 management. The results of the present study can thereby provide vital scientific basis for lake 460 ecosystem protection and for the sustainable utilization of biodiversity resources.

\section{Acknowledgements}

465 466 467 468 469 470 471

\section{References}

473 474 475 (13006457) .
We are grateful to Liu GH, Yan JY, Zeng ZG, Zhang XC, Zeng T, AN CT, Guo GY, Huang WG, Lv Q, Hou JJ, Zhang XL for their assistance in the field and laboratory. We are also grateful to Waigen Huang for improving the language of the manuscript. This project was funded by National Natural Science Foundation of China (31560133, 41501028), International Crane Foundation (11001903) and Key Laboratory of Ministry of Education, Nanchang University

Baranyi C, Hein T, Holarek C, Keckeis S, Schiemer F. Zooplankton biomass and community structure in a Danube River floodplain system: effects of hydrology [J]. Freshwater Biology, 2002, 47 (3): 473-482. 
476 Bērziņš B, Pejler B. Rotifer occurrence in relation to pH [J]. Hydrobiologia, 1987, 147 (1): $107-$ $477 \quad 116$.

478 Castro BB, Gonçalves F. Seasonal dynamics of the crustacean zooplankton of a shallow 479 eutrophic lake from the Mediterranean region [J]. Fundamental and Applied Limnology, $480 \quad 2007,169(3): 189-202$.

481 Chen XL, Zhang Y, Zhang L, Chen LQ, Lu JZ. Distribution characteristic of nitrogen and 482 phosphorus in Lake Poyang during high water period [J]. Journal of Lake Sciences, 2013, 483 25(5): 643-648.

484 Clarke KR, Warwick RM. Changes in Marine Communities: An Approach to Statistical Analysis 485 and Interpretation [M]. PRIMER-E Ltd., Plymouth, 1994, 144 pp.

486 Crustacean Research Group, Institute of Zoology, Chinese Academy of Sciences. China Fauna, 487 Arthropoda, Crustacea, Freshwater Copepoda [M]. Beijing: Science Press, 1979, 301-418, 488 (in Chinese).

489 Dai GF, Zhang M, Feng ML, Hong JY, Liu ZG. Analysis of cyanobacteria bloom in Nanjishan 490 Natural Reserve in Poyang Lake [J]. Ecological Science, 2015, 34(4): 26-30.

491 Deng DG, Xie P, Zhou Q, Yang H, Guo LG, Geng H. Field and experimental studies on the 492 combined impacts of cyanobacterial blooms and small algae on crustacean zooplankton in a 493 494 495 496 497 498 large, eutrophic, subtropical, Chinese lake [J]. Limnology, 2008, 9: 1-11.

Deng ZJ, Li Q, Cheng JF. A Preliminary Investigation Report on the Cladocera of Poyang Lake: Study on the Natural Food Resources of Poyang Lake (I) [J]. Journal of Nanchang University (Science Edition), 1963, 00:141-151.

Deyzel HP. The zooplankton and hyperbenthos of the Mngazana Estuary with reference to two tidal creeks [D]. 2004, University of Port Elizabeth.

Dodson SL. Complementary feeding niches sustained by size-selective predation [J]. Limnology 501 502 503 504 and Oceanography, 1970, 15: 131-137.

Gal G, Skerjanec M, Atanasova N. Fluctuations in water level and the dynamics of zooplankton: a data-driven modelling approach [J]. Freshwater Biology, 2014, 58(4): 800-816.Ge G, Ji WT, Liu CL, Xiong S, Wu ZQ. Hydraulic project and wetland ecological project in Poyang Lake [J]. Resources and Environment in the Yangtze Basin, 2010, 19 (6): 606-613. 
505 Gilbert JJ. Kairomone-induced morphological defenses in rotifers. In Tollrian R, Harvell CD 506 (eds.), The ecology and evolution of inducible defenses [M]. Princeton University Press, 507 Princeton, NJ, 1999, 127-141.

508 Goździejewska A, Glińska-Lewczuk K, Obolewski K, Grzybowski M, Kujawa R, Lew S, 509 Grabowska M. Effects of lateral connectivity on zooplankton community structure in 510 floodplain lakes [J]. Hydrobiologia, 2016, 774(1): 7-21.

511 Hairston NG, Hansen AM, Schaffner WR. The effect of diapause emergence on the seasonal 512 dynamics of a zooplankton assemblage [J]. Freshwater Biology, 2000, 45 (2): 133-145. Han

513 MS, Shu YF. Chinese freshwater biology atlas [M]. Beijing: Ocean Press, 1995: 156-296, 514 (in Chinese).

$515 \mathrm{Hu}$ CB, Xi YL, Tao LX. Comparative on the life history characteristics of Brachionus rubens 516 and B. urceolaris [J]. Acta Ecologica Sinica, 2008, 28 (12): 5957-5963.

$517 \mathrm{Hu}$ MH, Yang LL, Liu QG. Do physicochemical variables regulate the distribution of

518

519

520

521

522

523

524

525

526

527

528

529

530

531

532

533

534

535

zooplankton communities in reservoirs dominated by filter-feeding carp [J]. Chinese Journal of Oceanology and Limnology, 2014, 32 (2): 266-277.

Hu MM, Zhu X. Present Situation of Cyanobacteria outbreak in Freshwater Lakes in China and governance ideas [J]. Academic Proceedings of the Chinese Society of Environmental Science, 2014, 3502-3510.

Hu ZP, Ge G, Liu CL. Response of wintering migratory birds to hydrological processes in Poyang Lake[J]. Journal of Natural Resources, 2014, 29 (10): 1770-1779.

Hu ZP, Zhang ZF, Liu YZ, Ji WB, Ge G. The function and significance of the Shallow-Lakes in the Poyang Lake wetland ecosystem [J]. Jiang Xi Hydraulic Science and Technology, 2015, 41(5): 316-323.

$\mathrm{Hu} \mathrm{ZP}$. The habitat characteristics of white cranes to live through the winter in Poyang Lake and the reaction for water level changing in the lake [J]. Jiangxi Science, 2012, 30 (1): 30-35.

Huang FP, Sun AR, Wang ZL, Yang YL, Huang JZ. Spatial and Temporal Distribution of Zooplankton in the Jiaozhou Bay [J]. Advances in marine science, 2010, 28 (3): 332-341.

Huang JG, Guo ZY. The wetland biodiversity and its conservation countermeasures in the Poyang Lake [J]. Research of Soil and Water Conservation, 2007, 14 (1): 305-306+309.

Hussain A, Sulehria AQK, Ejaz M, Maqbool A. Population dynamics of rotifers in the floodplain of River Ravi, Pakistan[J]. Pakistan Journal of Zoology, 2016, 48 (1): 215-225.

Peer] reviewing PDF | (2019:01:34721:2:0:NEW 28 Jul 2019) 
536 Inaotombi S, Gupta PK, Mahanta PC. Influence of abiotic factors on the spatio-temporal 537 distribution of rotifers in a subtropical lake of western Himalaya [J]. Water Air and Soil 538 Pollution, 2016, 227 (2): 1-15.

539 Jiang XZ, Du NS. China Fauna, Arthropoda, Crustacea, Freshwater Cladocera [M]. Beijing: 540 Science Press, 1979, 80-271, (in Chinese).

541 Korpelainen $\mathrm{H}$. The effects of temperature and photoperiod on life history parameters of 542 Daphnia magna (Crustacea: Cladocera) [J]. Freshwater Biology, 1986, 16 (5): 615- 620.

543 Krylov AV. Interannual changes in the summer zooplankton in the lakes of the Khopyor River 544 flood plain [J]. Biology Bulletin, 2015, 42 (10): 891-898.

545 Li RD, Liu JY. An Estimation of wetland vegetation biomass in the Poyang Lake using Landsat 546 ETM data [J]. Acta Geographica Sinica, 2001, 56 (5): 531-539.

547 Lin Q, You WH, Xu FJ, Yu QJ, Yu HG. Zooplankton community structure and its relationship $548 \quad$ with environmental factors in Dishui Lake [J]. Acta Ecologica Sinica, 2014, 34 (23): 6918$549 \quad 6929$.

550 Liu BG, Liu X, Wu Y, Zhong Z, Chen YW. Spatial and temporal distribution characteristics of 551 planktonic crustaceans in Lake Poyang [J]. Acta Ecologica Sinica, 2016, 36 (24): 82055528213.

553 Liu QC, Hu W, Ge G, Xiong Y, Lai JH, Wu L. Contents of nutrients and heavy metals in the 554 Poyang Lake during dry season[J]. Resources and Environment in the Yangtze Basin, 2012, 55521 (10): 1230-1235.

556 Lv LJ. Investigation on Poyang Lake water pollution by Eutrophication [J]. Journal of Lake 557 Science, 1996, 8 (3):241-247.

558 Mamani A, Koncurat ML, Boveri M. Combined effects of fish and macroinvertebrate predation 559 on zooplankton in a littoral mesocosm experiment [J]. Hydrobiologia, 2019, 829: 19-29. 560 Nie X, Hu XR, Liu GH, Jin BS, Qin HM. Species diversity of zooplankton and water quality 561 biological assessment in a sub-lake of Poyang Lake [J]. Journal of Nanchang University 562 (Natural Science), 2018, 42(2): 161-167.

563 Ning LF, Xi YL, Sun Q, Zhou A. Combined effects of temperature and algal food density on life 564 table demography of Brachionus diversicornis (Rotifera) [J]. Journal of Lake Sciences, $565 \quad 2013,25$ (2): 295-301. 
566 Pereira R, Soares AMVM, Ribeiro R, Goncalves F. Assessing the trophic state of Linhos lake: a 567 first step towards ecological rehabilitation [J]. Journal of Environmental Management, $568 \quad 2002,64(3): 285-297$.

569 Peter HW, Sigrid BS, Shuhei N. Introduction to species diversity of marine zooplankton [J].

570 Deep Sea Research Part II: Topical Studies in Oceanography, 2010, 57 (24/25/26): 20615712063.

572 Qi SH, Liu Y, Yu XB, Liao FQ. Effect of "Lake Enclosed in Autumn” on the habitat of winter 573 bird in Poyang Lake [J]. Resources and Environment in the Yangtze Basin, 2011, S1: 18-21. 574 Rettig JE, Schuman LS, Mccloskey JK. Seasonal patterns of abundance: Do zooplankton in 575 small ponds do the same thing every spring-summer? [J]. Hydrobiologia, 2006, 556 (1): $576 \quad 193-207$.

577 Romo S. Seasonal zooplankton patterns in a shallow oligotrophic lake: Loch Rusky (Scotland)

578 [C]. Annales de Limnologie-International Journal of Limnology, 1990, 26(1): 11-17.

579 Scheffer M, Rinaldi S, Kuznetsov YA, Nes EHV. Seasonal dynamics of Daphnia and algae $580 \quad$ explained as a periodically forced predator-prey system [J]. Oikos, 1997, 80 (3): 519-532.

581 Shi XL, Shi XB. Reproduction and development of Simocephalus himalayensis microdus

582 (Crustacean: Cladocera) [J]. Acta Zoological Sinica, 1996, 42 (3): 287-296.

583 Sommer U. The PEG-model of seasonal succession of planktonic events in fresh waters [J]. 584 Archiv Fur Hydrobiologie, 1986, 106 (4): 433-471.

585 Soto D, Rios PDL. Influence of trophic status and conductivity on zooplankton composition in 586 lakes and ponds of Torres del Paine National Park (Chile) [J]. Biologia, 2006, 61(5): 541$587 \quad 546$.

588 Steiner CF. Daphnia dominance and zooplankton community structure in fishless ponds [J]. 589 Journal of Plankton Research, 2004, 26 (7): 799-810.

590 Szulc, B, Szulc, K, Kruk, A. Indicator Value (IndVal) as a tool for analysing habitat preferences 591 of diatom taxa: a case study in the Pilica River, Poland. 2010, DOI: 10.13140/2.1.2104.7049 592 Tao LX, Xi YL, Hu CB. Characteristics in life history of Brachionus forcatus and B. caudatus: a 593 comparative study [J].Chinese Journal of Applied Ecology, 2008, 19 (5):1104-1109.

594 Ter Braak CJF, Smilauer P. Canoco for Windows version 4.5 [M]. Biometrics: Plant Research 595 International, Wageningen. 2002. 
596 Threlkeld ST. The midsummer dynamics of two Daphnia species in Wintergreen Lake, Michigan $597 \quad[\mathrm{~J}]$. Ecology, 1979, 60(1): 165-179.

598 Wang JJ. Rotifera Sinicarum Aquae Dulcis [M]. Beijing: Science Press, 1961, 21-282, (in 599 Chinese).

600 Wang JQ, Wu JP, Yu YB, Wang TY, Cheng G. The specific list, quantitative distribution and 601 change of zooplankton in the season of spring and autumn in Poyang Lake [J]. Journal of 602 Lake Science, 2003, 15 (4): 345-352.Wang ML, Zhou WB, Hu CH. Status of nitrogen and 603 phosphorus in waters of Lake Poyang Basin [J]. Journal of Lake Science, 2008, 03: 334604338.

605 Wang T. Predation and competition: Interspecies interactions of zooplankton communities in 606 Liuxihe reservoir [D]. 2010, Jinan University.

607 Wang ZF, Wu B, Luo YT, Jin LW, Cai Y, Chen DH, Wang QX. Investigation over the 608 distribution of the zooplankton community constitution in the west Taihu Lake basin [J]. 609 Journal of Safety and Environment, 2012, 12 (6): 150- 156.

610 Wen Y, Qin HM, Hu XR, Hu HL. Characterization of Summer Zooplankton (Rotifer and 611 Crustacean) Community and Water Quality Assessment of Three Typical Nanchang Lakes. 612 Journal of Hydroecology, 2015, 36(2): 46-54.

$613 \mathrm{Wu}$ JT. Evaluation of the wetland ecosystem of the Poyang Lake National Nature Reserve in 614 Jiangxi Province [J]. Journal of Natural Resources, 1994, 9(4): 333-340.

615 Wu ZS, Cai YJ, Liu X, Xu CP, Chen YW, Zhang L. Temporal and spatial variability of 616 phytoplankton in Lake Poyang: The largest freshwater lake in China[J]. Journal of Great 617 Lakes Research, 2013, 39(3): 476-483.

618 Xie QM, Li CC, Peng CL. Preliminary Studies on Community Ecology of Protozoan in Poyang 619 Lake [J]. Jiangxi Science, 2000, 18(1): 40-44.

620 Xie QM, Li Y, Li CC. Studies on seasonal changes of the species composition and standing crop 621 of Rotifera in Poyang Lake [J]. Jiangxi Science, 1997, 15(4): 235-242.

622 Xie QM, Li CC. Studies on the composition and seasonal variations of planktonic Copepoda in 623 Poyang Lake [J]. Jiangxi Science, 1998, 16(3): 180-187.

624 Yang W, Deng D, Zhang S, Hu C. Seasonal dynamics of crustacean zooplankton community 625 structure in Erhai Lake, a plateau lake, with reference to phytoplankton and environmental 626 factors [J]. Chinese Journal of Oceanology and Limnology, 2014, 32 (5), 1074-1082. 
627 Zeng ZG, Zhang XC, Liu GH, Jin JF, Chen JK, JIN BS. Structure and Features of Fishery

628 Resources of Sub-lakes in Poyang Lake, Jiangxi, China [J].Resources and Environment in 629 the Yangtze Basin, 2015, 24(6): 1021-1029.

630 Zhang B, Wang JH. Preliminary opinions on fishery natural resources, protection and utilization 631 in Poyang Lake [J]. Freshwater fisheries, 1982, 03:1-5.

632 Zhang B, Study on Poyang Lake [M]. Shanghai: Shanghai Science and Technology Press, 1988, $633 \quad 13-17$.

634 Zhang T, Ma XH, Wang GP, Li DL, Jin BS, Qin HM. Community structure and spatial 635 distribution of plankton in the Poyang Lake national nature reserve, China [J]. Acta 636 Hydrobiologica Sinica, 2014, 38 (1): 158-165.

637 Zhang ZS, Huang XF. Research Methods on Freshwater Plankton [M]. Beijing: Science Press, 638 1991, 358-362, (in Chinese).

639 Zheng L, Chen B, Liu X, Huang B, Liu H, Song S. Seasonal variations in the effect of 640 microzooplankton grazing on phytoplankton in the East China Sea [J]. Continental Shelf 641 Research, 2015, 111: 304-315.

642 Zhou J, Han X, Qin B, Casenave C, Yang G. Response of zooplankton community to turbulence 643 in large, shallow Lake Taihu: a mesocosm experiment [J]. Fundamental and Applied 644 Limnology, 2016, 187(4): 315-324.

645 Zhu Q, Liu GH, Jin JF. Natural Resources Monitoring Report of Jiangxi Poyang Lake National 646 Nature Reserve (2013-2014) [M]. Shanghai: Fudan University press, 2014, (in Chinese). 
Figure 1

Location of Shahu Lake and the zooplankton sampling points (water depth map based on the water level of October 2012)

(A) Location of the Poyang Lake. (B) Location of Jiangxi Poyang Lake National Nature Reserve.

(C) Location of Shahu Lake. (D) Zooplankton sampling points in Shahu Lake. 

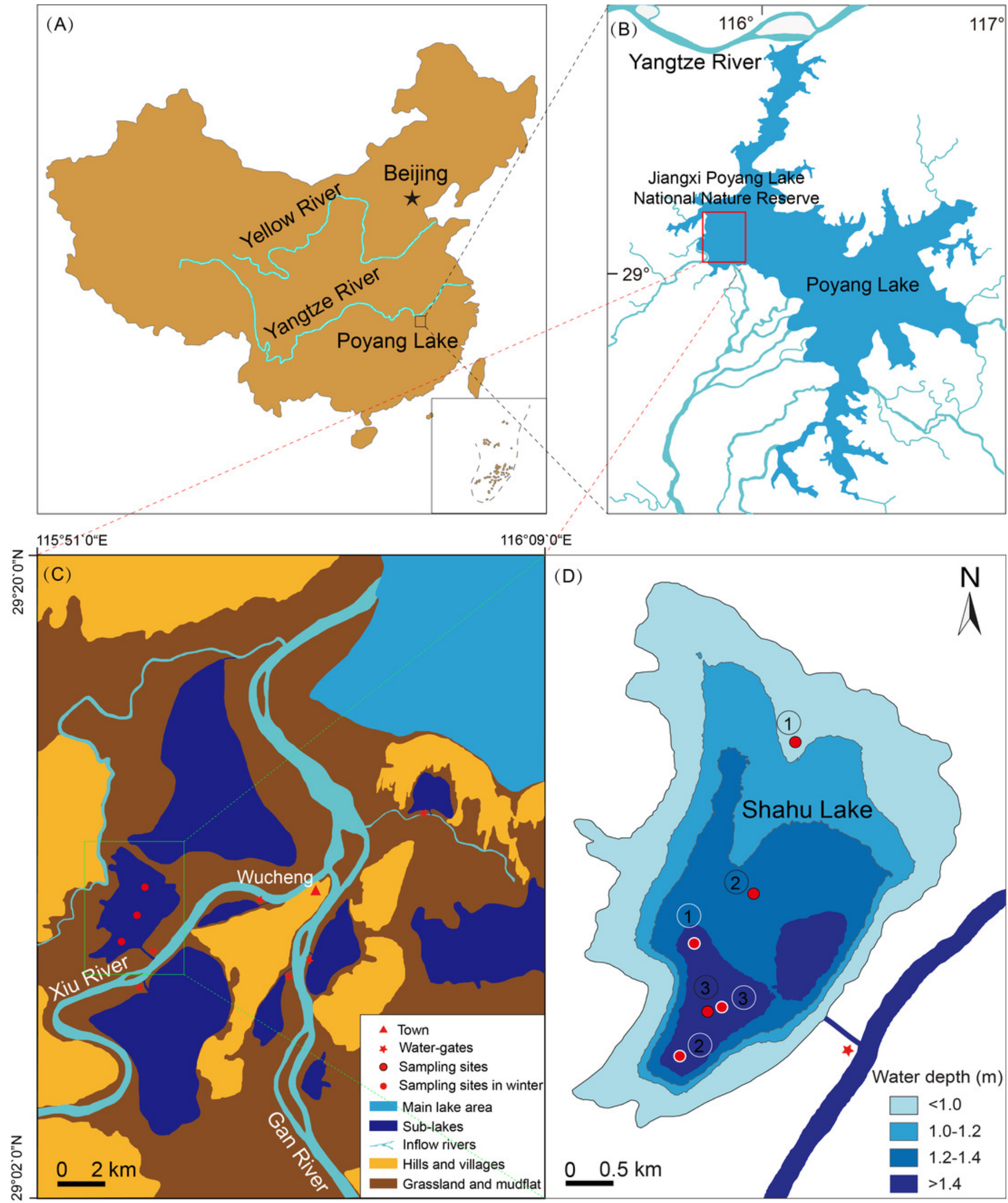
Figure 2

Seasonal variation in species richness of main zooplankton groups in Shahu Lake from April 2012 to January 2016

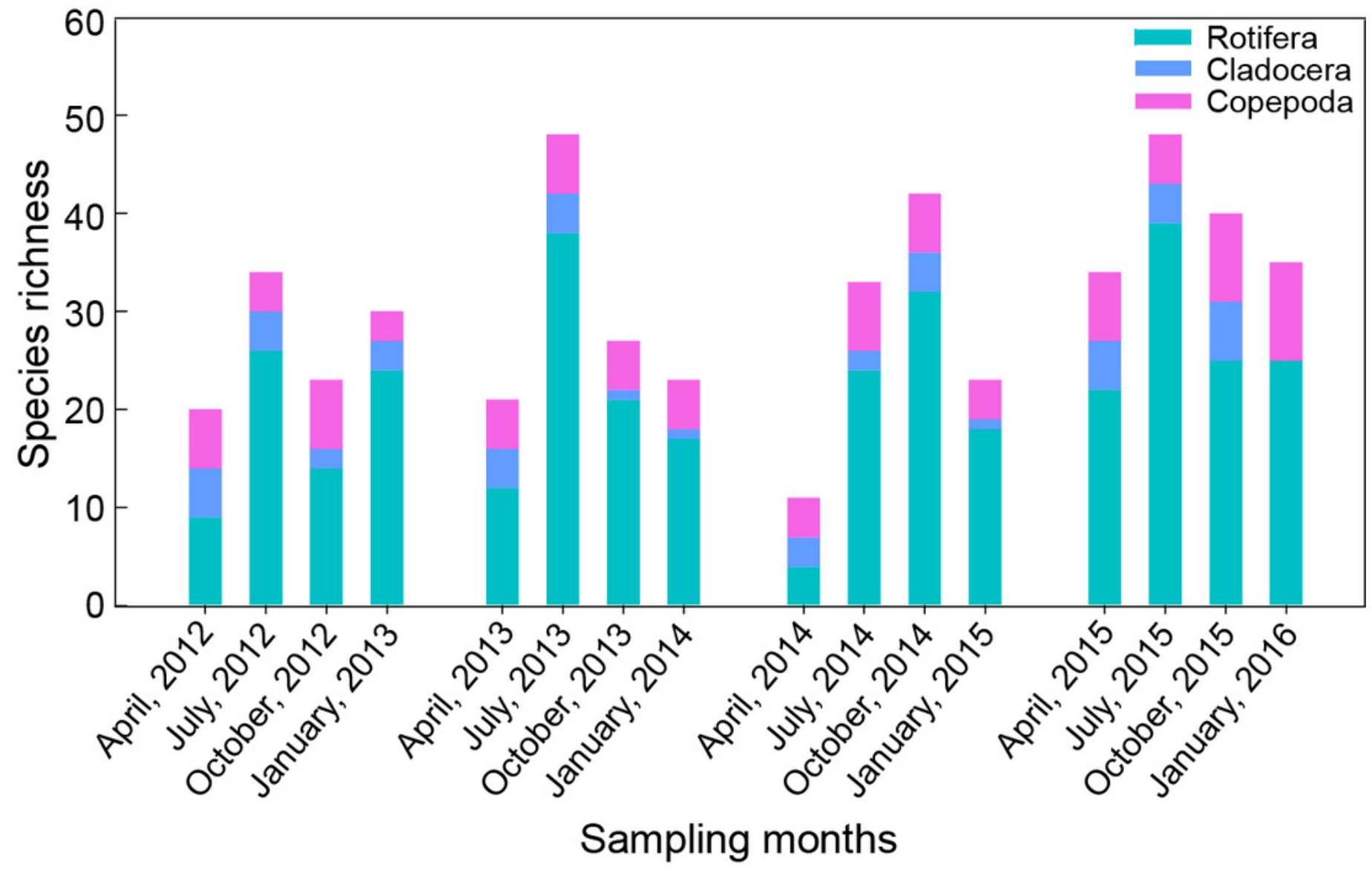


Figure 3

Seasonal variation in mean density (ind./L) and biomass (mg/L), relative density and biomass (\%) of each group (Rotifera, Cladocera and Copepoda) in Shahu Lake during 2012-2015

(A) Density variation. (B) Biomass variation. 


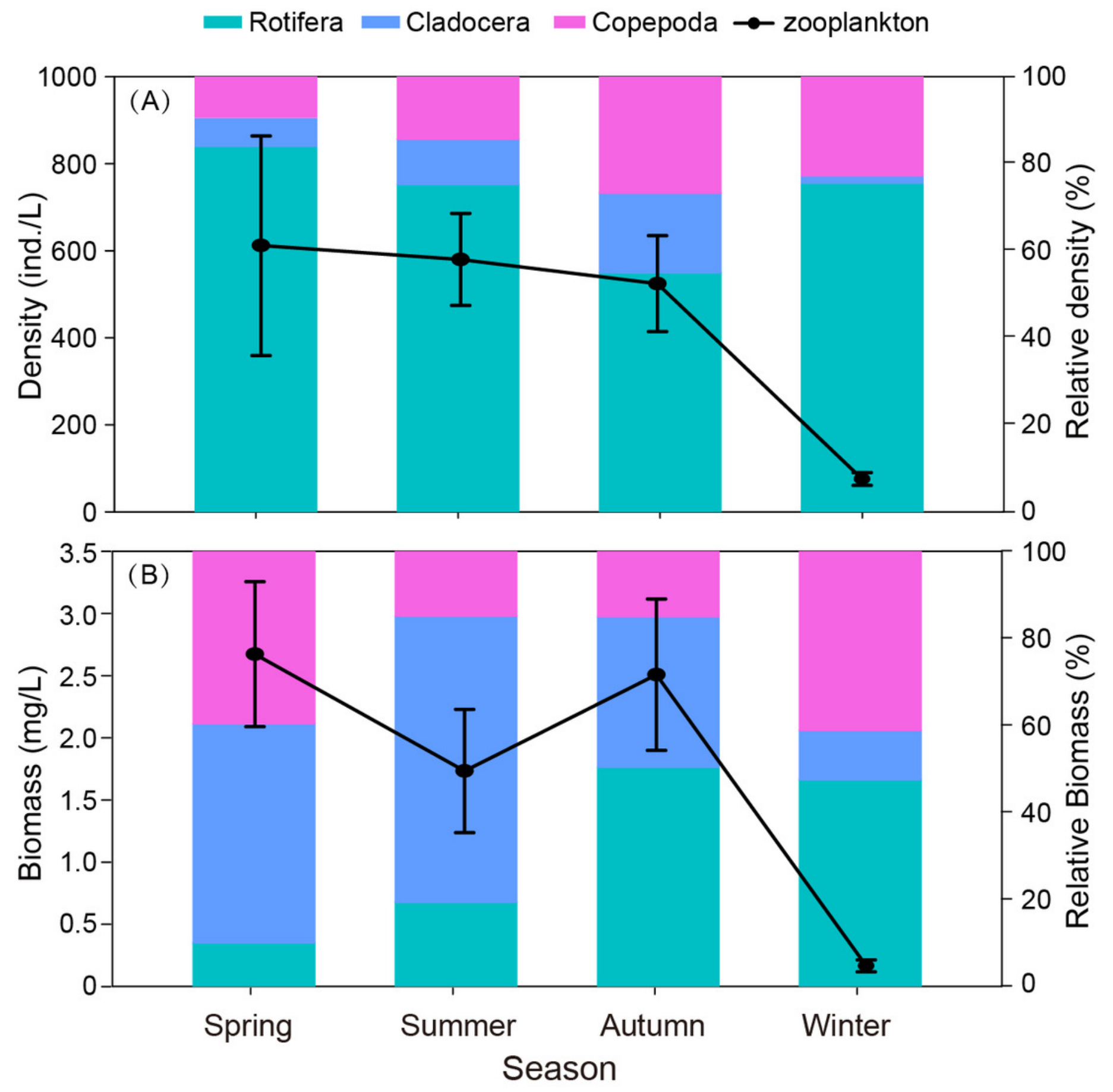


Figure 4

Interannual differences in density (ind./L) and biomass (mg/L), relative density and biomass (\%) of zooplankton in Shahu Lake during 2012-2015

(A) Density variation. (B) Biomass variation.
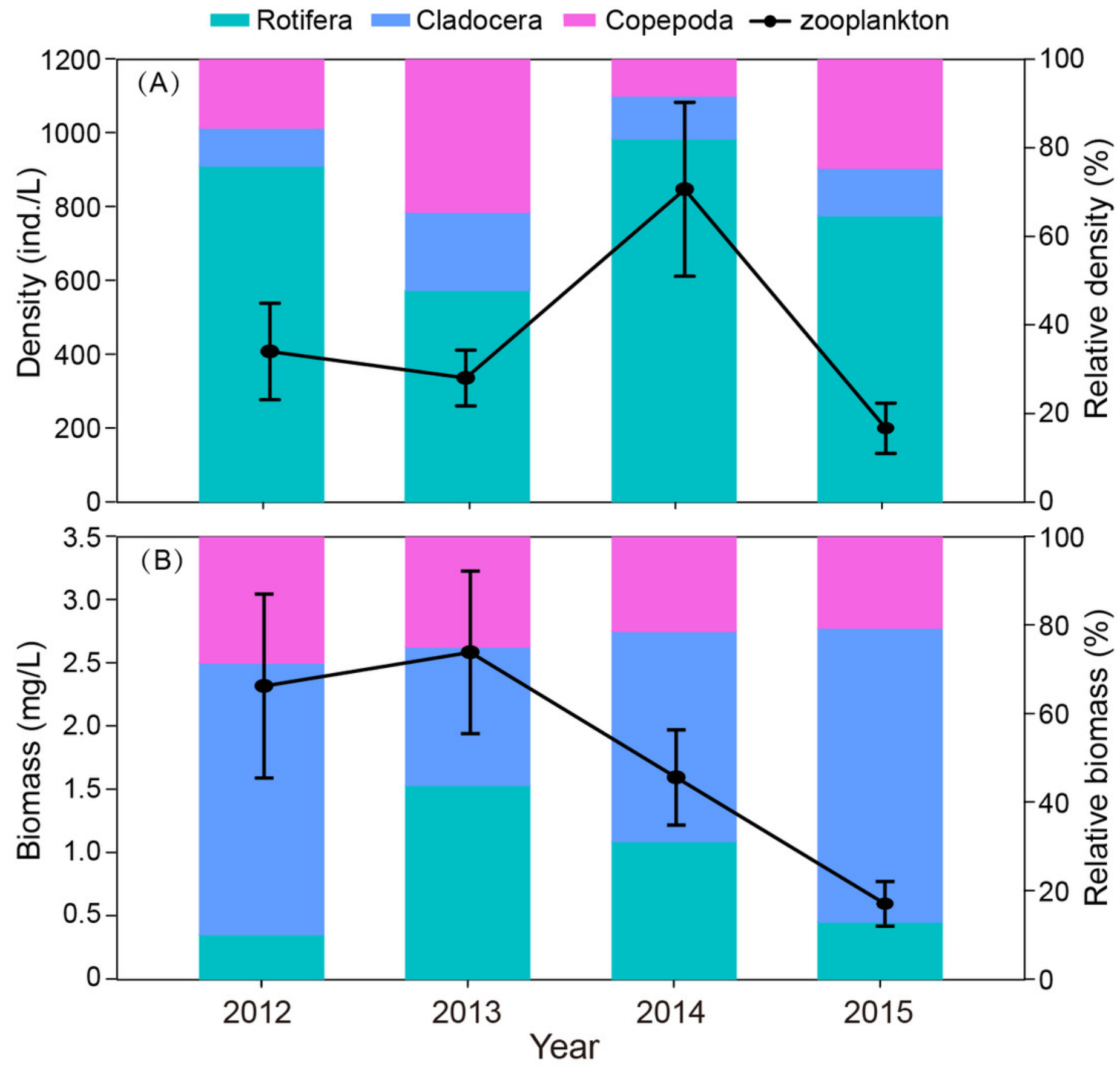
Figure 5

Seasonal variation in biodiversity index in Shahu Lake during 2012-2015
(A) Shannon-Weiner index, $\mathrm{H}^{\prime}$.
(B) Margalef index,
D. (C) Pielou's index, J'.

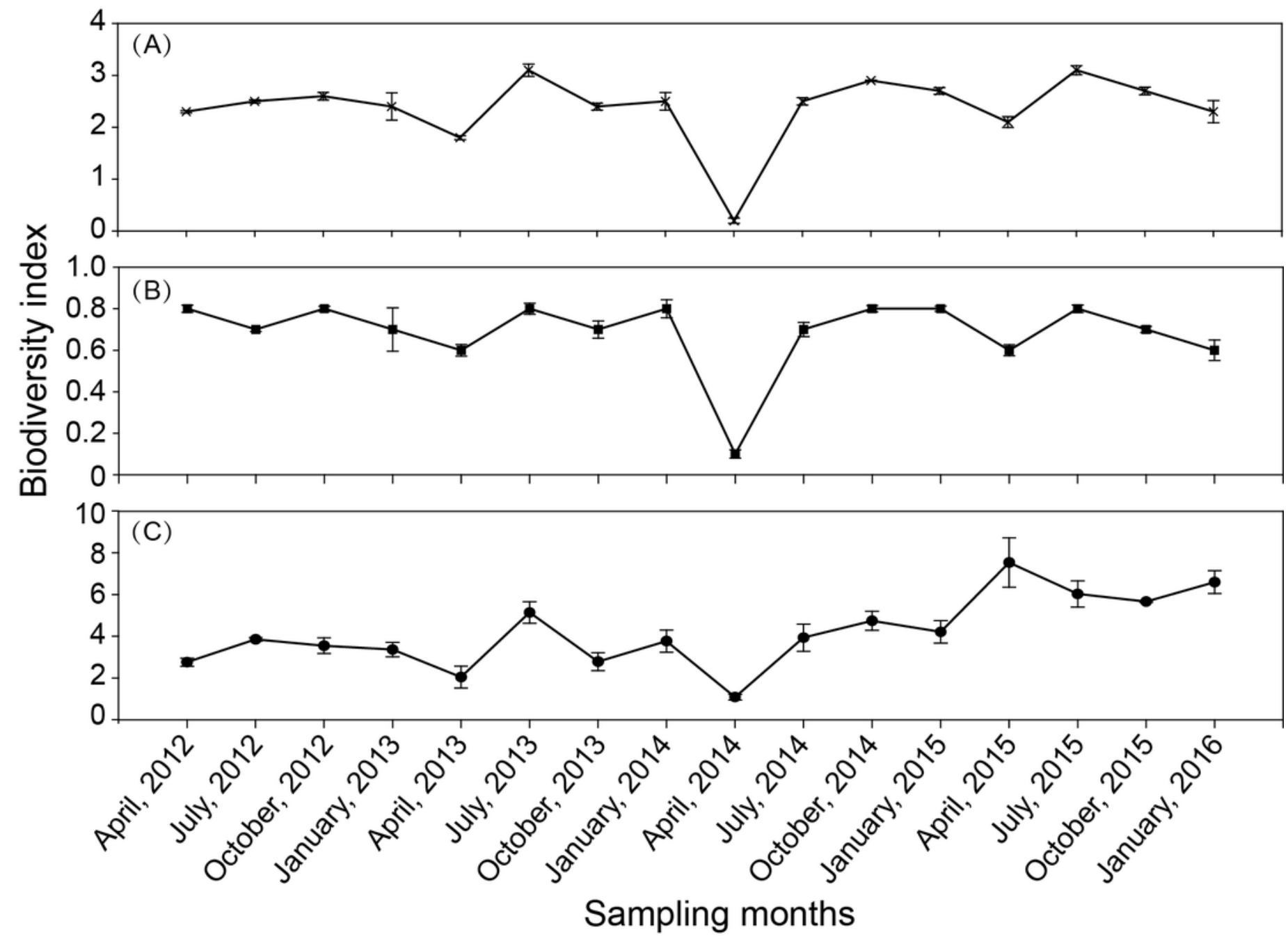


Figure 6

Non-metric multidimensional scaling ordination (NMDS) of zooplankton communities

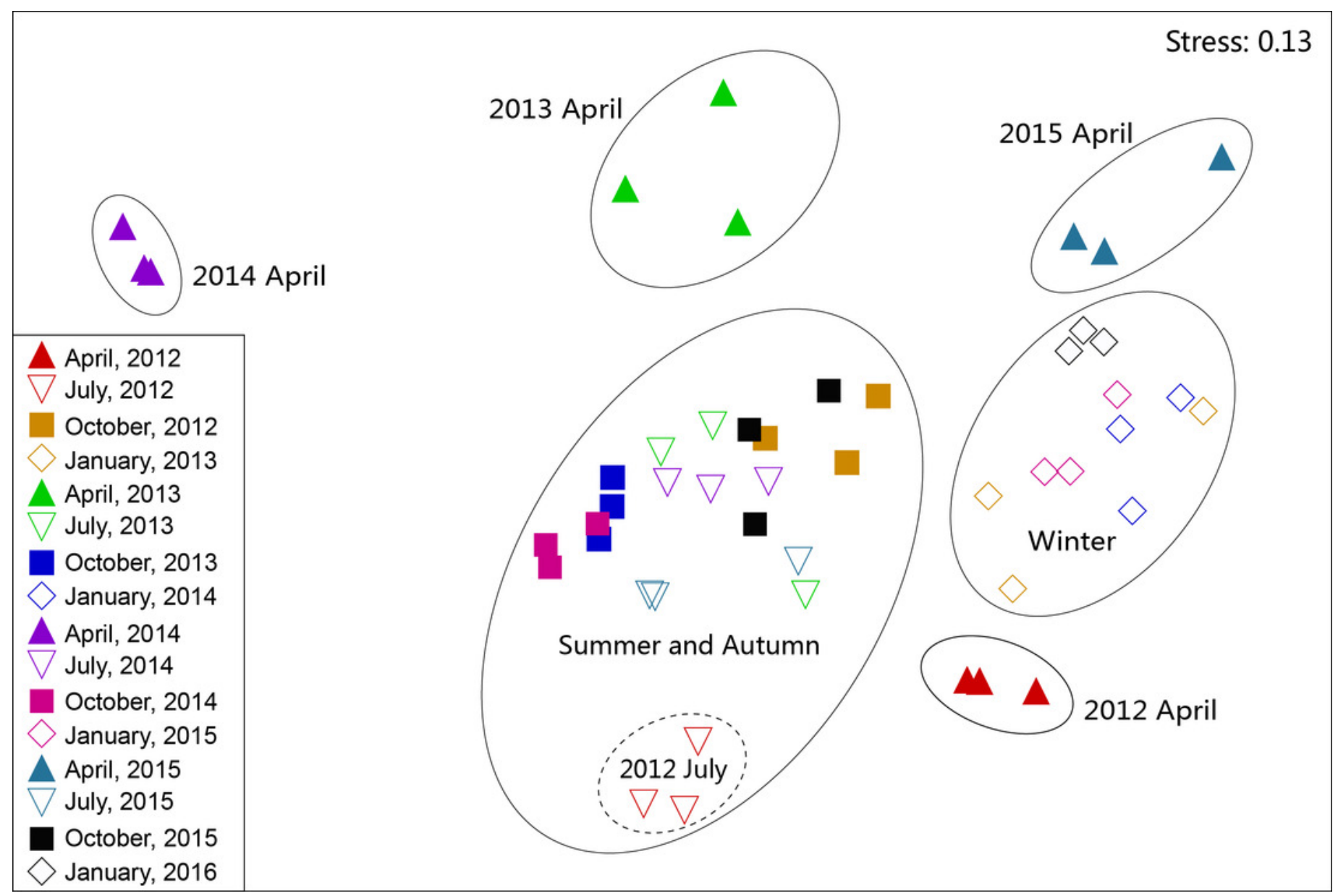


Figure 7

Redundancy analysis (RDA) of zooplankton dominant species and environmental factors in Shahu Lake (WT, water temperature; Cond, conductivity; DO, dissolved oxygen; Turb, turbidity)

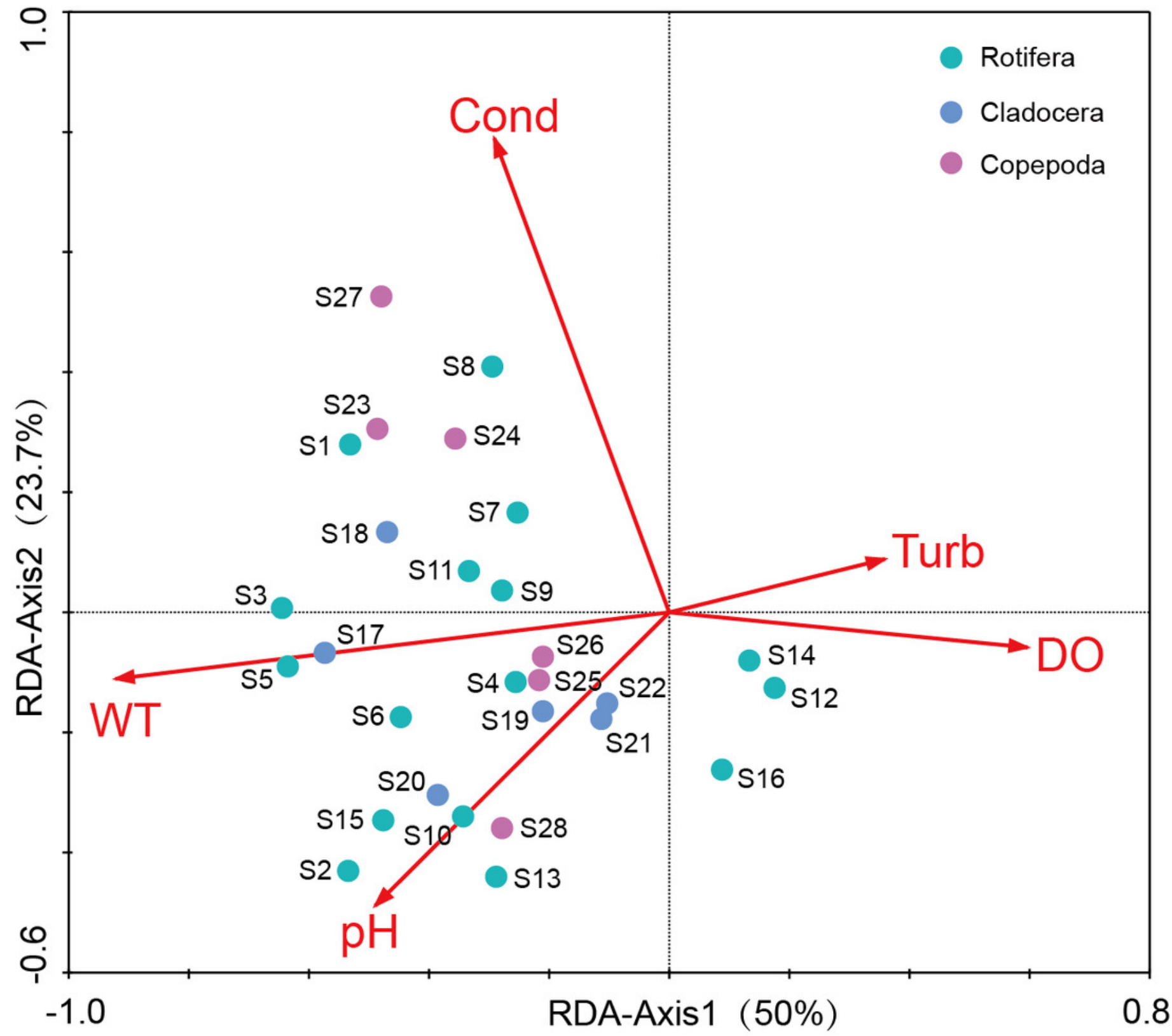


Figure 8

Interannual variation of zooplankton dominant species density in summer and autumn and diurnal variation of water level in 4 years of Shahu Lake.

(A) Interannual variation of zooplankton dominant species density in summer. (B) Interannual variation of zooplankton dominant species density in autumn. (C) diurnal variation of water level in 4 years. (D) Differences in the number of fishes that may enter the sub-lake after hydrological connectivity.
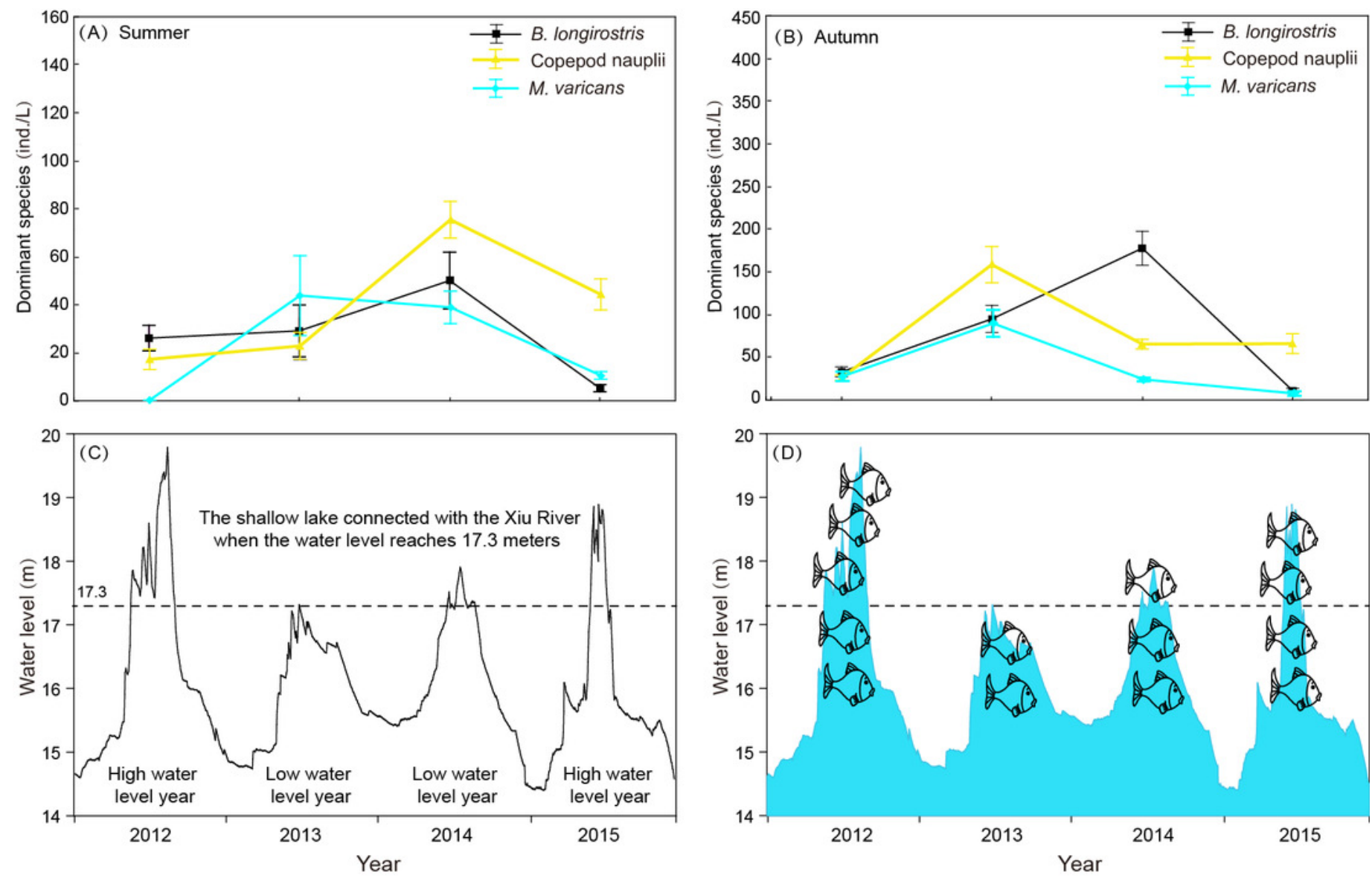


\section{Table $\mathbf{1}$ (on next page)}

Mean values ( \pm standard error) of physicochemical factors and their effects on the density of zooplankton in Shahu Lake $(n=48)$ 
1 Table 1. Mean values ( \pm standard error) of physicochemical factors and their effects on the 2 density of zooplankton in Shahu Lake $(n=48)$.

\begin{tabular}{|c|c|c|c|c|c|c|}
\hline & April & July & October & January & $\mathrm{F}$ & $P$ \\
\hline Water temperature $\left({ }^{\circ} \mathrm{C}\right)$ & $20.8 \pm 1.13^{\mathrm{a}}$ & $29.4 \pm 0.39^{\mathrm{b}}$ & $21.3 \pm 0.21^{\mathrm{a}}$ & $9.2 \pm 0.58^{\mathrm{c}}$ & 152.48 & $<0.001$ \\
\hline Conductivity $(\mu \mathrm{S} / \mathrm{cm})$ & $90.2 \pm 4.35^{\mathrm{a}}$ & $229.0 \pm 68.51^{\mathrm{ab}}$ & $532.6 \pm 128.79^{b}$ & $279.3 \pm 94.28^{\mathrm{ab}}$ & 4.52 & 0.008 \\
\hline Dissolved oxygen $(\mathrm{mg} / \mathrm{L})$ & $8.8 \pm 0.15^{\mathrm{a}}$ & $5.9 \pm 0.60^{\mathrm{b}}$ & $8.9 \pm 0.20^{\mathrm{a}}$ & $11.0 \pm 0.35^{\mathrm{c}}$ & 32.74 & $<0.001$ \\
\hline $\mathrm{pH}$ & $7.1 \pm 0.20^{\mathrm{ab}}$ & $7.5 \pm 0.21^{\mathrm{a}}$ & $7.1 \pm 0.20^{\mathrm{ab}}$ & $6.7 \pm 0.16^{\mathrm{b}}$ & 3.08 & 0.037 \\
\hline Turbidity (NTU) & $82.1 \pm 15.37^{\mathrm{ab}}$ & $35.1 \pm 7.92^{\mathrm{a}}$ & $112.4 \pm 23.84^{\mathrm{b}}$ & $142.1 \pm 21.69^{b}$ & 6.24 & 0.001 \\
\hline
\end{tabular}

3

4 
Table 2 (on next page)

Dominant species, mean density (ind./L) and dominance ( $\mathrm{Y}$ ) for each year in Shahu Lake during 2012-2015 
1 Table 2. Dominant species, mean density (ind./L) and dominance (Y) for each year in Shahu

$2 \quad$ Lake during 2012-2015.

\begin{tabular}{|c|c|c|c|c|c|}
\hline Dominant species & $\begin{array}{c}2012 \\
\text { ind./L (Y) }\end{array}$ & $\begin{array}{c}2013 \\
\text { ind./L (Y) }\end{array}$ & $\begin{array}{c}2014 \\
\text { ind./L (Y) }\end{array}$ & $\begin{array}{c}2015 \\
\text { ind./L (Y) }\end{array}$ & Code \\
\hline \multicolumn{6}{|l|}{ Rotifera } \\
\hline Brachionus angularis & $0.9(0.001)$ & $12.6(0.024)$ & $8(0.006)$ & $5.7(0.023)$ & $\mathrm{S} 1$ \\
\hline Brachionus forficula & $5.1(0.004)$ & $3.2(0.004)$ & $1.1(0.000)$ & $5.8(0.023)$ & $\mathrm{S} 2$ \\
\hline Brachionus diversicornis & $7.6(0.013)$ & $3(0.006)$ & $0.5(0.000)$ & $5.6(0.022)$ & $\mathrm{S} 3$ \\
\hline Keratella cochlearis & $35.1(0.066)$ & $17.7(0.052)$ & $28(0.030)$ & $1.8(0.011)$ & $\mathrm{S} 4$ \\
\hline Keratella. valga & $5.8(0.008)$ & $16.5(0.049)$ & $13.1(0.009)$ & $22.7(0.088)$ & S5 \\
\hline Asplanchna priodonta & $4.8(0.003)$ & $12(0.035)$ & $25.6(0.018)$ & $5.1(0.034)$ & S6 \\
\hline Asplanchna. girodi & $9.3(0.021)$ & $1(0.001)$ & $0.1(0.000)$ & $0.1(0.000)$ & S7 \\
\hline Asplanchna. brightwel & $1(0.000)$ & $19.6(0.037)$ & $1.9(0.001)$ & $0.2(0.000)$ & S8 \\
\hline Ascomorpha ecaudis & - & $30.9(0.134)$ & $6.5(0.003)$ & $0.2(0.000)$ & S9 \\
\hline Trichocerca cylindrical & $11.3(0.013)$ & $0.1(0.000)$ & $12.9(0.009)$ & $4.9(0.020)$ & $\mathrm{S} 10$ \\
\hline Polyarthra trigla & - & $4.9(0.013)$ & $23.5(0.017)$ & $4.2(0.023)$ & $\mathrm{S} 11$ \\
\hline Polyarthra dolichoptera & $57.2(0.139)$ & $3.6(0.007)$ & $3.9(0.001)$ & $2.3(0.009)$ & $\mathrm{S} 12$ \\
\hline Polyarthra vnlgaris & $81.9(0.133)$ & - & $10(0.004)$ & - & $\mathrm{S} 13$ \\
\hline Synchaeta oblonga & $24.6(0.031)$ & $3.7(0.006)$ & $2.4(0.001)$ & $0.6(0.002)$ & S14 \\
\hline Filinia longiseta & $3.4(0.002)$ & $0.3(0.000)$ & - & $10.3(0.042)$ & $\mathrm{S} 15$ \\
\hline Conochilus unicornis & - & $0.8(0.001)$ & $495.6(0.654)$ & $22.1(0.167)$ & $\mathrm{S} 16$ \\
\hline \multicolumn{6}{|l|}{ Cladocera } \\
\hline Diaphanosoma brachyurum & $2.8(0.034)$ & $3.3(0.009)$ & $6.5(0.042)$ & $8.5(0.210)$ & $\mathrm{S} 17$ \\
\hline Bosmina longirostris & $15.2(0.267)$ & $43.3(0.551)$ & $66.4(0.808)$ & $4.7(0.160)$ & $\mathrm{S} 18$ \\
\hline Bosmina coregoni & - & $10.9(0.026)$ & $8.6(0.043)$ & - & S19 \\
\hline Bosminopsis deitersi & $1.5(0.007)$ & - & - & $5.3(0.083)$ & $\mathrm{S} 20$ \\
\hline Daphnia pulex & $8.4(0.053)$ & - & - & - & $\mathrm{S} 21$ \\
\hline Daphnia hyalina & $5.5(0.030)$ & - & - & - & $\mathrm{S} 22$ \\
\hline \multicolumn{6}{|l|}{ Copepoda } \\
\hline Copepods nauplii & $18.6(0.264)$ & $48.7(0.374)$ & $37.4(0.479)$ & $33.1(0.677)$ & $\mathrm{S} 23$ \\
\hline Limnoithona sinensis & - & $13.6(0.078)$ & $5.1(0.038)$ & $3.1(0.033)$ & $\mathrm{S} 24$ \\
\hline Macrocyclops fuscus & $18.6(0.198)$ & - & - & $0.2(0.001)$ & $\mathrm{S} 25$ \\
\hline Tropocyclops prasinus & $6(0.048)$ & - & - & - & S26 \\
\hline Microcyclops varicans & $12.8(0.090)$ & $33.6(0.161)$ & $16.6(0.179)$ & $4.7(0.072)$ & $\mathrm{S} 27$ \\
\hline Mesocyclops leuckarti & - & - & $4.3(0.015)$ & $5.3(0.066)$ & $\mathrm{S} 28$ \\
\hline
\end{tabular}

$3-$, the species density is very small or does not appear. 
Table 3 (on next page)

Eigenvalues of the first and second axes in the redundancy analysis 
1 Table 3. Eigenvalues of the first and second axes in the redundancy analysis.

\begin{tabular}{lccc}
\hline Axes & RDA1 & RDA2 & Total variance \\
\hline Eigenvalues : & 0.156 & 0.074 & 1 \\
Species-environment correlations : & 0.754 & 0.806 & \\
Cumulative \% variance & & & \\
$\quad$ of species data : & 15.6 & 23 & \\
$\quad$ of species-environment relation : & 50 & 73.7 & 1 \\
& & & \\
Sum of all eigenvalues & & & 0.313 \\
Sum of all canonical eigenvalues & & & \\
\hline
\end{tabular}

2

3 
Table 4 (on next page)

Species list of zooplankton in Shahu Lake, 2012-2015 
1 Appendix Table 1. Species list of zooplankton in Shahu Lake, 2012-2015.

\begin{tabular}{|c|c|c|c|c|c|c|c|c|c|c|c|c|c|c|c|c|}
\hline \multirow{2}{*}{ Zooplankton species } & \multicolumn{4}{|c|}{2012} & \multicolumn{4}{|c|}{2013} & \multicolumn{4}{|c|}{2014} & \multicolumn{4}{|c|}{2015} \\
\hline & Spring & Summer & Autumn & Winter & Spring & Summer & Autumn & Winter & Spring & Summer & Autumn & Winter & Spring & Summer & Autumn & Winter \\
\hline \multicolumn{17}{|l|}{ Rotifera } \\
\hline Anarthra aptera & & & & & & & & & & + & & & & & & \\
\hline Argonotholca foliacea & & & & & & & & & & & & & & ++ & & \\
\hline Ascomorpha ecaudis & & & & & +++ & +++ & +++ & & & + & +++ & & & + & & + \\
\hline Ascomorpha ovalis & & & & & & & + & & & + & ++ & & + & + & + & + \\
\hline Ascomorpha saltans & & +++ & & & + & + & & + & & & + & & & + & & \\
\hline Asplanchna brightwel & & + & & + & & + & +++ & & ++ & + & & & & + & & \\
\hline Asplanchna girodi & & +++ & +++ & +++ & & + & + & + & & & & + & & + & & \\
\hline Asplanchna priodonta & & ++ & & & + & +++ & +++ & & & & +++ & +++ & +++ & +++ & ++ & +++ \\
\hline Asplanchna sieboldi & & + & & & & & & & & & & & & & & \\
\hline Brachionus angularis & + & & ++ & & & ++ & +++ & & & +++ & ++ & & + & +++ & ++ & + \\
\hline Brachionus budapestiensis & + & & +++ & + & & + & + & +++ & & + & ++ & +++ & & +++ & + & \\
\hline Brachionus calyciflorus & + & + & ++ & + & & + & & & & & + & & & + & & +++ \\
\hline Brachionus capsuliflorus & & & & & & & & & & & + & +++ & + & + & + & \\
\hline Brachionus caudatus & & & & & & + & & & & & & +++ & & & & \\
\hline Brachionus diversicornis & + & ++ & +++ & + & + & + & + & + & & & + & + & + & +++ & ++ & \\
\hline Brachionus falcatus & & +++ & & & & & & & & +++ & & +++ & & +++ & & \\
\hline Brachionus forficula & & ++ & & & & + & & + & & & + & ++ & & +++ & +++ & \\
\hline Brachionus leydigi & & & & & & & & & & & & & + & & & + \\
\hline Brachionus urceus & & & & + & & + & & + & & & & ++ & +++ & ++ & + & +++ \\
\hline Cephalodella catellina & & & & & & & & + & & & & & & & & \\
\hline Cephalodella gibba & + & & & + & & & & & & & & & & & & \\
\hline Cephalodella sterea & & & & & & & & & & & & & & + & & \\
\hline Collotheea mutabilis & & & & & & + & & & + & & & & & & & \\
\hline
\end{tabular}




\begin{tabular}{|c|c|c|c|c|c|c|c|c|c|c|c|c|c|c|c|c|}
\hline Conochiloides dossuarius & & & & & & & & & & ++ & ++ & & & & & \\
\hline Conochilus unicornis & & & & & & & & +++ & +++ & ++ & +++ & +++ & +++ & +++ & +++ & +++ \\
\hline Eosphora thoa & & & & & & + & + & & & & & & & & & + \\
\hline Eothinia elongata & & & & & & + & & & & & & & & & & \\
\hline Epiphanes senla & & ++ & & & & & + & & & & & & & & & \\
\hline Euchlanis dilatata & & & & & & & & & & & + & & + & + & & \\
\hline Filinia longiseta & & + & & & & + & & & & & & & + & +++ & +++ & \\
\hline Filinia maior & & + & & & & & + & & & & +++ & & & & & \\
\hline Filinia passa & & + & +++ & & & + & + & & & & & & & +++ & + & \\
\hline Gastropus hyplopus & & ++ & + & & + & + & & + & & & & & & & & \\
\hline Gastropus stylifer & & + & + & + & & & & & & + & & & & & & \\
\hline Harringia eupoda & & & & + & & & + & & & & & & & & & \\
\hline Kellicottia longispina & & + & & & & & & & & & & & & & & \\
\hline Keratella cochlearis & +++ & +++ & & + & & + & +++ & +++ & & ++ & +++ & +++ & ++ & ++ & ++ & + \\
\hline Keratella quadrata & & & & & & & & + & & + & & + & & & + & \\
\hline Keratella ticinensis & & & & & & & & & & & & & & + & ++ & \\
\hline Keratella valga & & ++ & + & & & +++ & +++ & + & & + & +++ & ++ & + & +++ & +++ & \\
\hline Lecane luna & & & & & & + & & & & & & & & & & \\
\hline Lecane nodosa & & & & & & & & & & & & & & & & + \\
\hline Lecane ungulata & & & & & & & & & & & & & & & & + \\
\hline Lepadella apsida & & & & + & & & & & & & & & & & & \\
\hline Lindia truncata & & & & & & & & & & & + & & & & & \\
\hline Monostyla crenata & & & & & & & + & & & & & & & & & \\
\hline Monostyla elachis & & & & & & & & & & & & & & ++ & & \\
\hline Monostyla lunaris & & & & & & & & & & & & & + & + & & \\
\hline Monostyla unguitata & & & & & & & & & & + & + & & & & & \\
\hline Mytilina ventralis & & & & & & + & & & & & & +++ & & & & \\
\hline Notholca labis & & & & & & & & + & & & & & & & & + \\
\hline Notommata tripus & & & & & & + & & & & & & & & & & \\
\hline
\end{tabular}




\begin{tabular}{|c|c|c|c|c|c|c|c|c|c|c|c|c|c|c|c|c|}
\hline Pedalia mira & & & & + & & + & & & & + & ++ & & & & & \\
\hline Ploesoma hudsoni & & & ++ & & + & + & & & + & ++ & & & +++ & & & \\
\hline Ploesoma truncatum & & & & + & & + & & & & + & & & & & & \\
\hline Polyarthra dolichoptera & +++ & +++ & ++ & +++ & & + & + & +++ & & & & +++ & ++ & + & + & + \\
\hline Polyarthra euryptera & & & & & & & & & & ++ & + & & + & & & \\
\hline Polyarthra trigla & & & & & + & + & +++ & + & & +++ & +++ & & + & +++ & +++ & +++ \\
\hline Polyarthra vnlgaris & ++ & +++ & + & + & & & & & & & +++ & & + & & & \\
\hline Pompholyx complanata & & & & + & & & + & & & & & & & & & \\
\hline Pompholyx sulcata & & & & & & & & & & + & + & & & & & \\
\hline Proales daphnicola & & & & & + & & & & & & & & & & & \\
\hline Pseudoharringia semilis & & & & & & + & & & & & & & & & & \\
\hline Resticula gelida & & & & & & + & & & & & & & & & & \\
\hline Resticula melandocus & & & & & & + & & & & & & & & & & \\
\hline Scaridum longicaudum & & ++ & & & ++ & + & & & & & & & & + & & \\
\hline Synchacta atylata & & & & + & & & & & & & + & & & & & \\
\hline Synchacta tremula & & & & + & & & & + & & & & + & & & & \\
\hline Synchaeta oblonga & & +++ & & +++ & + & + & & +++ & & & & +++ & + & & & +++ \\
\hline Synchaeta pectinata & & & & & & & & & & & & & + & + & & +++ \\
\hline Trichocerca bicristata & & & & & + & + & & & & & + & & & & & \\
\hline Trichocerca bicuspes & & & & & & & & & & & & & & + & + & \\
\hline Trichocerca capucina & & + & +++ & + & & +++ & & & & + & +++ & & & ++ & + & \\
\hline Trichocerca cylindrical & + & +++ & & + & + & & & & & +++ & +++ & & & ++ & +++ & + \\
\hline Trichocerca dixon-nuttalli & & & & & & & & & & & & & & + & & \\
\hline Trichocerca elongata & & & & & & & & & & & + & & & + & + & \\
\hline Trichocerca gracilis & & & & & & + & & & & & & & & +++ & + & + \\
\hline Trichocerca longiseta & & ++ & & + & & & & & & & & + & & & & \\
\hline Trichocerca lophoessa & & ++ & + & & & + & & & & & + & & & ++ & + & + \\
\hline Trichocerca pusilla & & & & & & & & & & & ++ & & & ++ & + & + \\
\hline Trichocerca rattus & & & & & & & & & & & & & & + & & + \\
\hline
\end{tabular}




\begin{tabular}{|c|c|c|c|c|c|c|c|c|c|c|c|c|c|c|c|c|}
\hline Trichocerca rousseleti & & & & & & & & & & & + & & & & & \\
\hline Trichocerca similis & & & & & & & & & & & & & + & + & + & \\
\hline Trichocerca stylata & & & & & & + & & & & + & +++ & & & & & \\
\hline Trichocerca tenuior & & & & & & & & & & + & & & & + & & \\
\hline Trichocerca weberi & & & & + & & + & + & & & & & & & & & + \\
\hline Trichotria tetractis & & & & & & & & & & & & & + & & & + \\
\hline \multicolumn{17}{|l|}{ Cladocera } \\
\hline Alonella rostrata & & + & & & & & & & & & & & & & & \\
\hline Bosmina coregoni & & & & & & +++ & & & ++ & & +++ & & & & & \\
\hline Bosmina fatalis & & & & & & & & & & & & & + & & ++ & \\
\hline Bosmina longirostris & + & +++ & +++ & + & +++ & + & +++ & + & ++ & +++ & +++ & ++ & +++ & ++ & +++ & \\
\hline Bosminopsis deitersi & & + & & + & & & & & & & & & & +++ & + & \\
\hline Daphnia cucullata & & & & + & & & & & & & & & +++ & & & \\
\hline Daphnia hyalina & +++ & & & & & & & & & & & & & & & \\
\hline Daphnia pulex & +++ & & & & & & & & & & & & + & & & \\
\hline Diaphanosoma brachyurum & + & + & +++ & & & +++ & & & + & ++ & ++ & & + & +++ & +++ & \\
\hline $\begin{array}{l}\text { Diaphanosoma } \\
\text { leuchtenbergianum }\end{array}$ & & & & & + & + & & & & & & & & + & + & \\
\hline Leptodora kindti & & + & & & + & & & & & & & & & & & \\
\hline Moina micrura & & & & & + & & & & & & & & & & & \\
\hline Sida crystallina & + & & & & & & & & & & ++ & & & & ++ & \\
\hline \multicolumn{17}{|l|}{ Copepoda } \\
\hline Copepod nauplii & +++ & ++ & +++ & +++ & ++ & +++ & +++ & +++ & + & +++ & +++ & +++ & +++ & +++ & +++ & +++ \\
\hline Cyclops vicinus & & & & & & & & & & & & & + & & & + \\
\hline Limnocletodes behningi & & & & & + & + & & & & & & & & & & \\
\hline Limnoithona sinensis & & & & & & +++ & + & +++ & + & +++ & + & & & ++ & +++ & + \\
\hline Macrocyclops fuscus & +++ & ++ & ++ & & & & & & & & & & +++ & & & \\
\hline Mesocyclops leuckarti & & & & & & & & & & & ++ & & & +++ & +++ & + \\
\hline Microcyclops varicans & +++ & & +++ & +++ & & + & +++ & + & & +++ & +++ & +++ & + & +++ & +++ & ++ \\
\hline
\end{tabular}




\begin{tabular}{|c|c|c|c|c|c|c|c|c|c|c|c|c|c|c|c|c|}
\hline Neodiaptomus schmackeri & & & & & & & & & & & & & ++ & & ++ & + \\
\hline Paracyclops fimbriatus & & & & & & & & & & & & & + & & & + \\
\hline Schmackeria forbesi & + & & + & & & & & & ++ & ++ & + & & & & + & + \\
\hline Sinocalanus dorrii & ++ & + & + & & +++ & + & + & + & ++ & + & & + & ++ & & + & + \\
\hline Thermocyclops hyalinus & & & & + & & & & & & + & & & & & & \\
\hline Thermocyclops kawamurai & +++ & & + & & ++ & + & + & + & & ++ & + & + & & & + & + \\
\hline Thermocyclops taihokuensis & & & & & & & & & & & & & & + & ++ & \\
\hline Tropocyclops prasinus & +++ & + & ++ & & & & & & & & & & & & & \\
\hline
\end{tabular}

2 Note: + means appeared; ++ means common species (occurrence frequency greater than 0.65 ); +++ means dominant species (dominance index greater than 0.02 ). 


\section{Table 5 (on next page)}

Summary of indicator species analysis showing indicator value (IV) and $p$ values for each group. $\mathrm{S}=$ spring, $\mathrm{SA}=$ summer and autumn, $\mathrm{W}=$ winter 
1 Appendix Table 2. Summary of indicator species analysis showing indicator value (IV) and $p$

2 values for each group. $\mathrm{S}=$ spring, $\mathrm{SA}=$ summer and autumn, $\mathrm{W}=$ winter.

\begin{tabular}{|c|c|c|c|}
\hline & Group & IV & $P$ values \\
\hline Sinocalanus dorrii & $\mathrm{S}$ & 90.62 & 0.001 \\
\hline Daphnia pulex & $\mathrm{S}$ & 33.33 & 0.004 \\
\hline Macrocyclops fuscus & $\mathrm{S}$ & 45.22 & 0.012 \\
\hline Daphnia hyalina & $\mathrm{S}$ & 25.00 & 0.032 \\
\hline Brachionus angularis & SA & 86.71 & 0.001 \\
\hline Brachionus forficula & SA & 56.50 & 0.001 \\
\hline Brachionus diversicornis & SA & 73.05 & 0.001 \\
\hline Keratella valga & SA & 90.29 & 0.001 \\
\hline Asplanchna priodonta & SA & 68.48 & 0.001 \\
\hline Ascomorpha ovalis & SA & 52.65 & 0.001 \\
\hline Trichocerca cylindrical & SA & 58.97 & 0.001 \\
\hline Trichocerca capucina & SA & 63.77 & 0.001 \\
\hline Pedalia mira & SA & 56.78 & 0.001 \\
\hline Diaphanosoma brachyurum & SA & 72.27 & 0.001 \\
\hline Bosmina longirostris & SA & 69.57 & 0.001 \\
\hline Copepod nauplii & SA & 75.76 & 0.001 \\
\hline Limnoithona sinensis & SA & 63.97 & 0.001 \\
\hline Microcyclops varicans & SA & 71.50 & 0.001 \\
\hline Polyarthra trigla & SA & 72.21 & 0.002 \\
\hline Filinia longiseta & SA & 41.64 & 0.007 \\
\hline Keratella cochlearis & SA & 64.85 & 0.009 \\
\hline Mesocyclops leuckarti & SA & 37.17 & 0.009 \\
\hline Collotheea mutabilis & SA & 33.33 & 0.014 \\
\hline Brachionus falcatus & SA & 34.57 & 0.019 \\
\hline Asplanchna brightwel & SA & 46.87 & 0.021 \\
\hline Trichocerca stylata & SA & 29.17 & 0.022 \\
\hline Scaridum longicaudum & SA & 31.97 & 0.023 \\
\hline Filinia maior & SA & 29.17 & 0.027 \\
\hline Bosminopsis deitersi & SA & 28.12 & 0.039 \\
\hline Brachionus budapestiensis & SA & 44.18 & 0.05 \\
\hline Synchaeta oblonga & $\mathrm{W}$ & 62.10 & 0.001 \\
\hline
\end{tabular}

3 